\title{
Die Invloed van Sekere Kontekstuele Faktore op Stemaanvangstyd, Vokaalduur en Uitingduur by Verbale Apraksie
}

\author{
A van der Merwe, D Phil (Pretoria) \\ I C Uys, D Phil (Pretoria) \\ Departement Spraakheelkunde en Oudiologie \\ Universiteit van Pretoria \\ J M Loots, D Sc (Fisiologie) (Pretoria) \\ Instituut vir Sportnavorsing, \\ Universiteit van Pretoria \\ R J Grimbeek, B Sc (Hons) (Pretoria) \\ Departement Statistiek, \\ Universiteit van Pretoria \\ L P C Jansen, D Sc (Fisika) (Pretoria) \\ Privaat praktiserende Akoestikus
}

\section{OPSOMMING}

Die konsep van konteks-sensitiviteit soos ontleen aan die koalisiemodel hou groot moontlikhede in vir die interpretasie van verbaal apraktiese simptome en vir 'n beter begrip van die aard van die afwyking. In hierdie ondersoek wat deel uitmaak van die groter ondersoek waarin die effek van variasie in kontekstuele faktore op verbaal apraktiese spraak nagegaan word (van der Merwe, Uys, Loots en Grimbeek, 1987; 1988), word die effek van die kontekstuele faktore, klankstruktuur en artikulasie-eienskappe op stemaanvangstyd, vokaalduur en uitingduur akoesties ontleed. Vier persone met verworwe verbale apraksie en een persoon met verbale ontwikkelingsapraksie is as proefpersone gebruik. Daar is bevind dat stemaanvangstyd nie konteks-sensitief is nie. Die stemaanvangstydfoute is nie ware vervangings met stemlose klanke nie, maar is onkonstante distorsies weens oorskryding van die kritiese temporale ekwivalensiegrense vir interartikulator-sinchronisasie. Vokaalduur en uitingduur, is wel konteks-sensitief. Namate die moeilikheidsgraad van die uiting toeneem, neem die afuryking in duur ook toe. Die temporale eienskappe van verbaal apraktiese spraak kan dus ook soos die ouditief waarneembare foute op grond van konteks. sensitiwiteit verdeel word in $\mid$ kernsimptome en geassosieerde simptome.

ABSTRACT

The concept of context sensitivity as borrowed from the coalition model has important implications for the interpretation of the symptoms of apraxia of speech and for a better understanding of the nature of the disorder. In this study which was part of the wider investigation into the effect of variation in contextual factors on apraxia of speech (van der Merwe, Uys, Loots and Grimbeek, 1987; 1988), the effect of two contextual factors namely sound structure and articulatory features on voice onset time, vowel duration and utterance duration was acoustically analysed. Four subjects with acquired apraxia of speech and one with developmental apraxia of speech were tested. Findings indicated that voice onset time is not context sensitive. Errors in voice onset time were not true substitutions with voiceless sounds but were inconsistent distortions due to an inability to keep interarticulator synchronization within the critical temporal boundaries of motor equivalence. Vowel and utterance du ration were found to be context sensitive. The deviation in duration increased with increased complexity of the utterance. As was the case with the auditorily perceived symptoms, the temporal characteristics of apraxia of speech can also be classified into core symptoms and associated symptoms based on their context sensitivity.

Sistematiese variasie in die kontekstuele faktore, klankstruktuur en artikulasie-eienskappe van 'n spraakuiting het ' $n$ invloed op die ouditief waarneembare foute by verbale apraksie en aanduidings van die aard van die:afwyking word daardeur verkry (van der Merwe, Uys, Loots \& Grimbeek, 1987 en 1988). Die vraag bestaan of variasie in hierdie kontekstuele faktore 'n akoesties aantoonbare invloed sal hê op die temporale eienskappe van verbaal apraktiese spraak en of dit ook aanduidings van die aard van die afwyking sal verskaf. Dit is bekend dat temporale versteurings een van die mees kenmerkende eienskappe van verbale apraksie is (Kent \& Rosenbek, 1983; Collins, Rosenbek \& Wertz, 1983; Itoh \& Sasanuma,
1984) en variasie in die graad en tipe aantasting sal moontlik waargeneem word met 'n variasie in bogenoemde kontekstuele faktore.

Akoestiese ondersoeke van die temporale eienskappe van verbaal apraktiese spraak waarvan verslag gedoen is in die literatuur is algemeen gemik op simptoombeskrywing (Wertz, La Pointe \& Rosenbek, 1984). Stadige spraakspoed, verlengde vokaalduur en swak koördinasie van stemgewing met ander artikulasiegebeure word as kenmerkende simptome van verbale apraksie beskryf (Blumstein, Cooper, Caramazza \& Zurif, 1977; Freeman, Sands \& Harris, 1978; Kent \& Rosenbek, 
1983). Die konteks waarin hierdie eienskappe ondersoek is, is egter in geen van hierdie studies gekontroleer en gevarieer nie.

Die teoretiese belang van kontekstuele faktore is volledig bespreek in van der Merwe et al. (1987). Die konsep van kontekssensitiwiteit is ontleen aan die koalisiemodel wat groot moontlikhede inhou vir toepassing op verbale apraksie (Kelso \& Tuller, 1981; Kelso, Tuller \& Harris, 1983). Variasie in kontekstuele faktore stel differensiële eise aan die beplanning en uitvoering van gedrag en die effek wat hierdie variasie op die waargenome simptome het, kan insiggewende gegewens verskaf oor die aard van die afwyking. Dit hou verder ook implikasies in vir die interpretasie van simptome en vir verdere navorsing. Die resultate van die ondersoek waarin die invloed van kontekstuele faktore op die ouditief waarneembare foute by verbale apraksie (van der Merwe, et al. 1987, 1988) nagegaan is, is die simptome van verbale apraksie wel in 'n nuwe en insiggewende perspektief gestel. Dit wil voorkom asof die simptome van verbale apraksie op grond van kontekssensitiwiteit verdeel kan word in kernsimptome en geassosieerde simptome.

In die huidige ondersoek wat deel uitmaak van die groter ondersoek waarin die effek van variasie in kontekstuele faktore op verbaal apraktiese simptome nagevors is, word die effek van sistematiese variasie op sekere temporale aspekte van verbaal apraktiese spraak akoesties ondersoek.

\section{METODE}

Doel

Die doel van die ondersoek is om te bepaal of sekere kontekstuele faktore in spraakproduksie, naamlik die klankstruktuur (foneemstruktuur) en die artikulasie-eienskappe (motoriese kompleksiteit) van 'n uiting 'n effek het op die volgende temporale aspekte van die spraak van persone met verbale apraksie:

- Interartikulator-sinchronisasie soos waargeneem in stemaanvangstyd.

- Segmentele tydsduur soos waargeneem in vokaalduur.
- Die spoed van spraak soos waargeneem in die duur van die uiting.

\section{Eksperimentele ontwerp.}

'n Tweegroepontwerp waarin die invloed van gekontroleerde stimuli op die temporale eienskappe van verbaal apraktiese spraak bepaal is deur vergelyking met die invloed op die spraak van afgepaarde kontrolepersone, is gebruik. Die kontrolepersone is afgepaar met betrekking tot ouderdom, geslag en spreektaal.

Die proefpersone, materiaal en prosedure van hierdie ondersoek is reeds volledig beskryf in 'n voorafgaande artikel (van der Merwe et al. 1987) en word dus nie hier herhaal nie. Kortliks kan wel gemeld word dat vier persone met verworwe verbale apraksie en een persoon met verbale ontwikkelingsapraksie as proefpersone gebruik is. Die kriterium is gestel dat 'n suiwer verbale apraksie vertoon moet word.

Wat die materiaal betref, is onsineenhede wat gekontroleer is in klankstruktuur en artikulasie-eienskappe ontwikkel (van der Merwe, 1986). Die vyf klankstruktuurgroepe (S) het elk agt eenhede bevat wat in vies artikulasie-eienskapgroepe (A) verdeel is. Vir die doel van die akoestiese analise is ses herhalings van vier eenhede in elke klankstruktuurgroep ontleed.

Apparaat vir die akoestiese analise.

Die akoestiese analise is uitgevoer in die forensiese akoestieklaboratorium van die Suid-Afrikaanse Polisie. Unieke apparaat wat ontwikkel is by die W.N.N.R. is vir die analise gebruik. Hierdie apparaat wat skematies voorgestel word in figuur 1 is verkies bokant die spektrograaf (wat ook beskikbaar was) omdat dit die spraaksein op so'n wyse kodeer op die ossiloskoop dat akkurate metings tot op die naaste millisekonde gemaak kan word.

- 'n S̄ony TC 1552-bandopnèmer voer die spraaksein na die digitale herhalingslyn Model $2 \mathrm{~A}$.

- Die beeld word vertoon op die skerm van 'n HewlettPackard 1200 B-tipe ossilloskoop.

- Daar is na die spraaksein geluister met 'n W770-kopstuk.

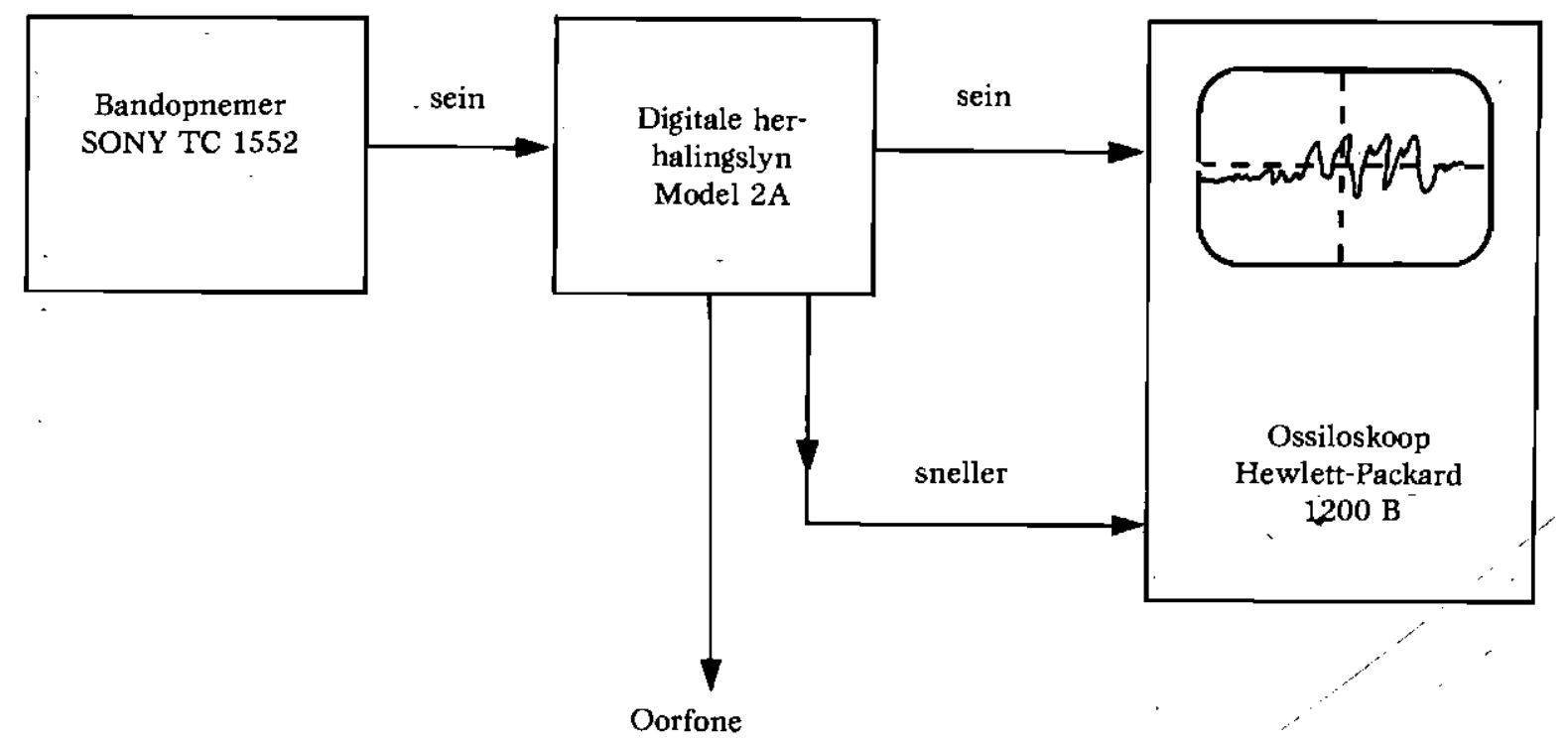

Figuur 1: Skematiese voorstelling van die apparaat vir die akoestiese analise. 
Prosedure vir die akoestiese analise.

Opleiding in die tegniek van akoestiese metings en die hantering van die akoestiese apparaat is ontvang van 'n akoestiese ingenieur, 'n kenner op die gebied van sprekerherkenning en akoestiese analises, wat dele van die apparaat ontwikkel het vir die W.N.N.R. Tydens die analises is alle probleemgevalle met hierdie persoon bespreek.

Die akoestiese metings is nie op al die eenhede toegepas nie, maar slegs op eenhede 1 tot 4 van elke klankstruktuurgroep. Die aantal eenhede in elke klankstruktuurgroep is vir die akoestiese ontledings beperk omdat dit duidelik geword het tydens ontleding dat die addisionele data geen verskil sal maak aan die uitslag van die ondersoek nie. Die akoestiese ontledings is ook tydrowend. Elk van die twintig uitings wat akoes ties ontleed is, is ses keer herhaal en die meting van hierdie honderd en twintig uitings het ongeveer twintig uur per persoon geduur.

Die data van twee van die drie Engelssprekende dames wat as kontroles opgetree het, is nie volledig ontleed nie. Nadat die analise van die eerste dame voltooi is, is steekproefontledings op die data van die ander twee gedoen. Daar is bevind dat die resultate grootliks ooreenkom en op aanbeveling van Jansen (1985) is die data van die eerste dame as kontrole vir die drie Engelssprekende proefpersone gebruik. Slegs ouderdom is in hierdie geval nie konstant gehou nie. Jansen (1985) beskou die data van een normale spreker as verteenwoordigend van normale spraak in die spesifieke taalgroep. Die data van die ander twee kontrolepersone is volledig ontleed.

Die spraakseinopnames van die kontrolepersone is eerste ontleed ten einde die tegniek volkome te bemeester alvorens die meer atipiese data van die proefpersone ontleed is. Voor elke meetsessie is vorige metings op 'n steekproefbasis herhaal ten einde die akkuraatheid te kontroleer. Dit het ook 'n oefengeleentheid gebied voordat die verdere metings voortgesit is. Die drie akoestiese metings van elke uiting is agtereenvolgens gedoen omdat dit die mees betroubare en tydbesparende metóde is.

Die drie metings is direk vanaf die ossilloskoopskerm in millisekondes gedoen. Die spraaksein is na die ossilloskoop gevoer soos uiteengesit in figuur 1 . Die gedeelte van die spraaksein wat in die digitale herhalingslyn se geheue ingelees en daar vasgevang is, is voortdurend herhaal. Hierdie digitale herhalingslyn stoor 2,5 sekondes spraak vir analise. Die spoed waarteen die beeld oor die skerm beweeg, kan verstel word van vyf tot twintig (of meer) millisekondes per divisie (wat aangebring is op die skerm) afhangende van die instelling wat die duidelikste beeld weergee by 'n spesifieke uiting. Die ondersoeker kan ook terselfdertyd na die herhaling luister.

Die tydsbasis van die ossilloskoop is gekalibreer en die metings kan direk van die skerm af gedoen word deur die aantal divisies op die skerm te tel. Hierdie getal is dan met die ingestelde aantal millisekondes per divisie van die itydsbasis vermenigvuldig om die tydsduur in millisekondes te verkry.

\section{Die meting van stemaanvangstyd.}

Meting van die stemaanvangstyd van die inisiële konsonante /b/en /d/ is gedoen. Die stemaanvangstyd word gemeet vanaf die begin van die ploffing tot by die aanvang van stemgewing vir die vokaal. Dit word as 'n positiewe waarde genoteer. Soms is daar 'n stemvoorloop en die meting word dan gedoen vanaf die begin daarvan tot by die ploffing. In dié geval word dit as 'n negatiewe waarde genoteer.

Tydens die meting van die eerste proefpersoon se data is bevind dat die norme van normale sprekers nie altyd voldoende riglyne verskaf vir eenvormige metings nie. Daar is toe begin om 'n reeks sketse van atipiese voorbeelde saam te stel namate dit opgeduik het. By elke volgende probleemgeval is dan terugverwys na die reeks vir riglyne vir meting of die nuwe voorbeeld is by die reeks ingevoeg.

Die ossilloskoopbeeld waarop die stemaanvangstyd gemeet is, word geillustreer in figure 2 tot 5 . Die metingspunte word ook aangedui.

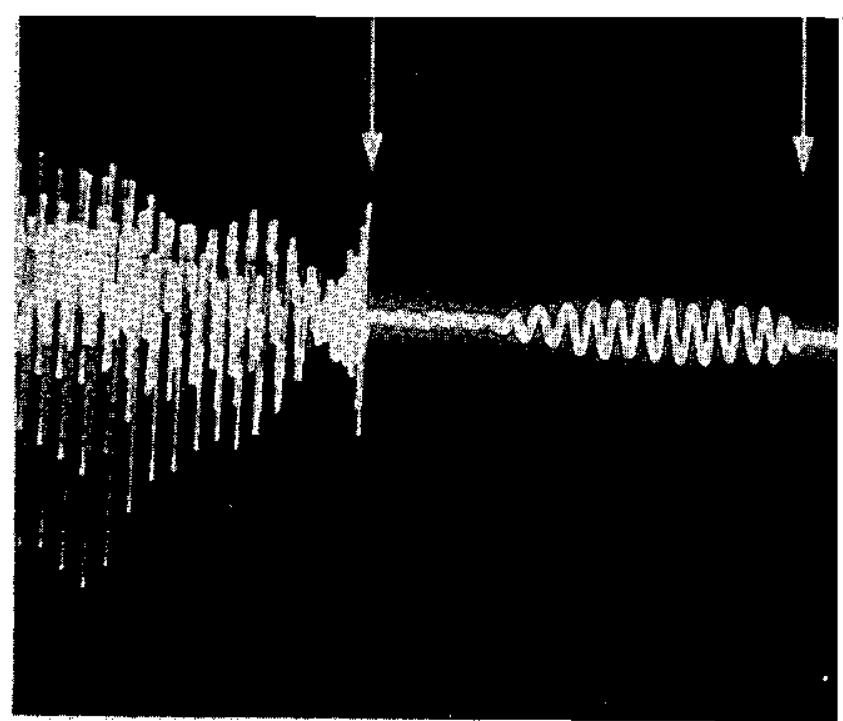

SAT: -80 millisekondes

(spoed: 20 millisekondes per divisie

Duur van beeld: 200 millisekondes)

Figuur 2: Voorbeeld van 'n negatiewe stemaanvangstyd by 'n normale spreker.

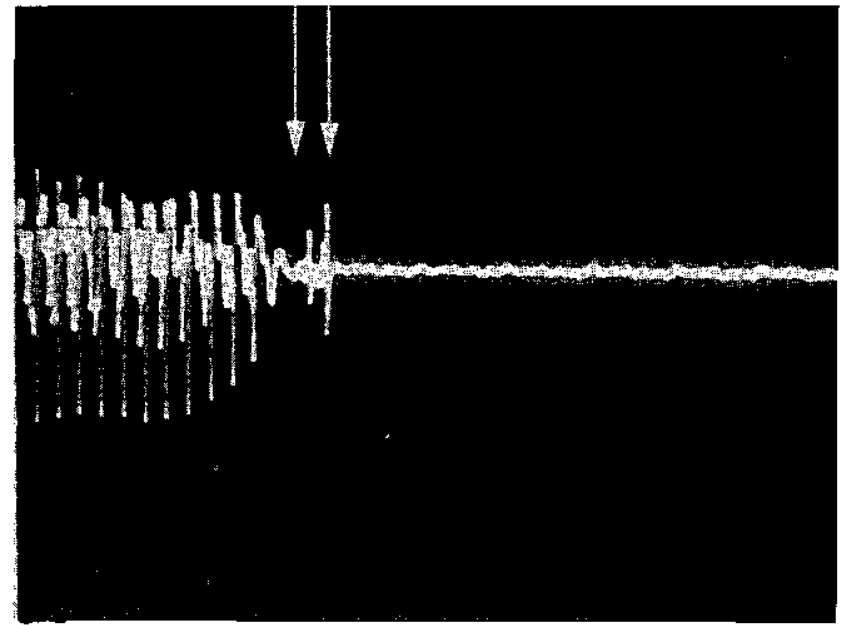

SAT: +10 millisekondes

(Spoed: 20 millisekondes per divisie Duur van beeld: 200 milliesekondes)

Figuur 3: Voorbeeld van 'n positiewe stemaanvangstyd by 'n normale spreker. 


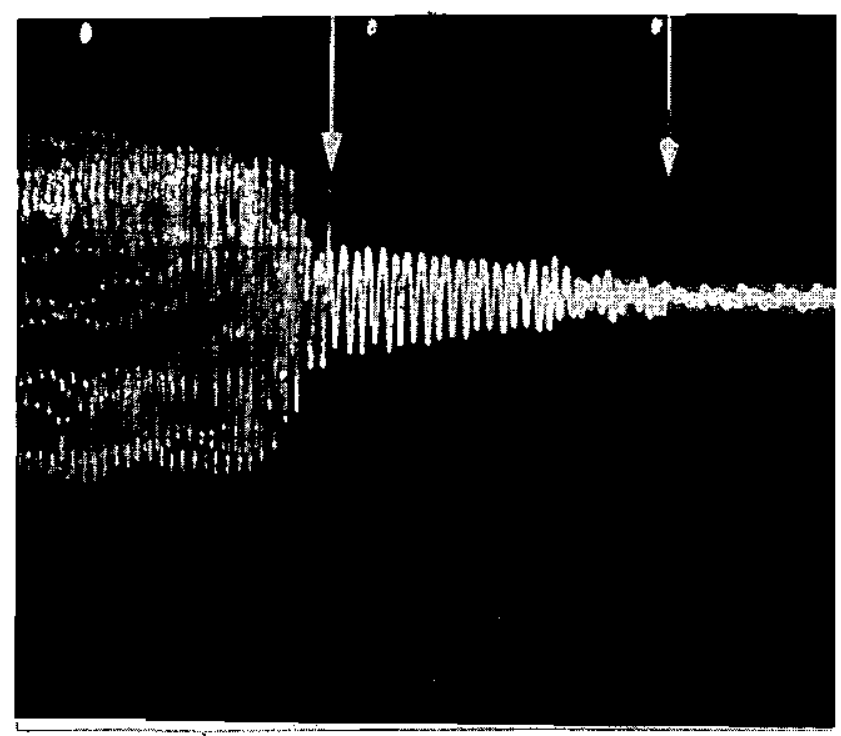

SAT: -176 millisekondes

(Spoed: 50 millisekondes per divisie

Duur van beeld: 500 millisekondes)

Figuur 4: Voorbeeld van 'n negatiewe stemaanvangstyd wat byna buite die normale perke val by'n verbaal apraktiese spreker.

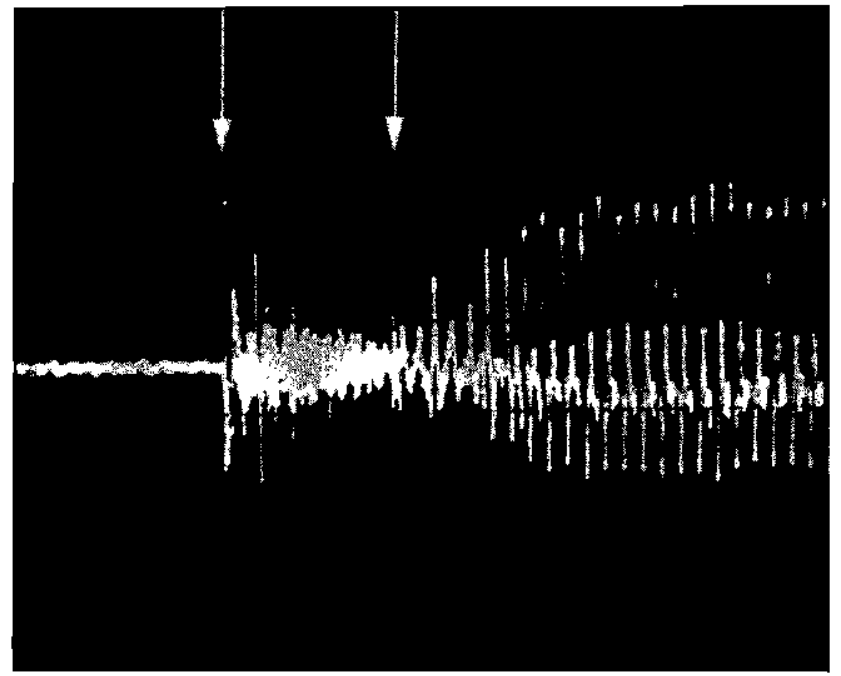

SAT: $+\mathbf{4 0}$ millisekondes

(Spoed: 20 millisekondes per divisie

Duur van beeld: 200 millisekondes)

Figuur 5: Voorbeeld van'n positiewe, maar atipiese stemaanvangstyd by 'n verbaal apraktiese spreker.

Die meting van vokaalduur.

Die duur van die eerste vokaal /a/ of $/ \mathrm{s} /$ is vanaf die ossilloskoopskerm in millisekondes gemeet. Die meting van vokaalduur is oor die algemeen 'n betroubare prosedure wat minder probleemgevalle oplewer as stemaanvangstyd. Die vokaal word aangedui deur 'n groot reëlmatige kurwe met'n lae frekwensie. Die meting word vanaf die begin van die kurwe tot by die laagste punt waar die kurwe afplat, gedoen. Die metingspunte van die vokaalduur word geïllustreer in figuur 6 .

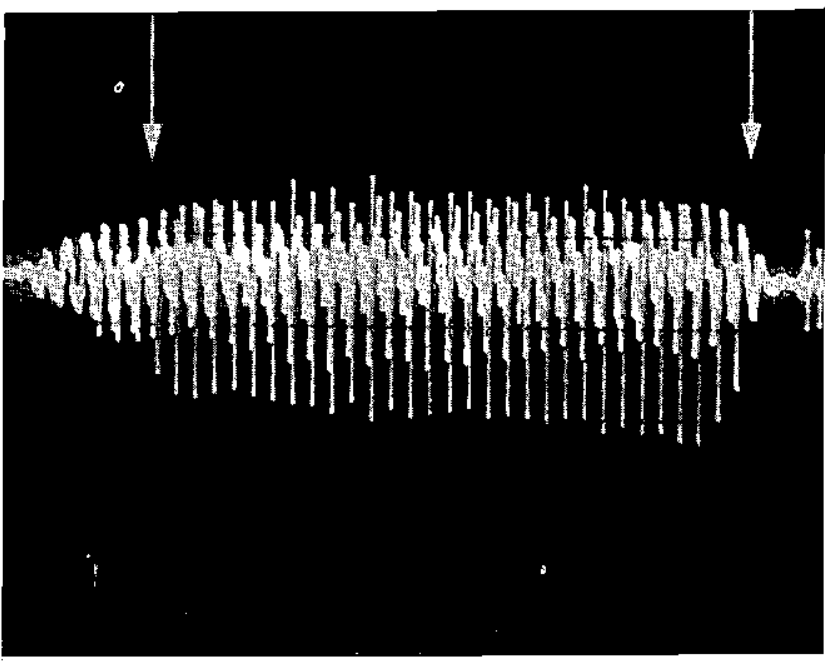

Vokaalduur: 164 millisekondes (Spoed: 25 millisekondes per divisie Duur van beeld: 250 millisekondes)

Figuur 6: Voorbeeld van die vokaalduur van 'n normale spreker.

Die meting van die duur van die uiting.

Die duur van die KVKV en KVK (in die geval van klankstruktuur 4) gedeelte van die eenhede is gemeet. Die meting van klankstruktuur 3 en 5 is beperk tot hierdie dele, omdat die roudata sodoende vergelykbaar is met die duur van klankstruktuur 1 en 2. Die produksie van die langer eenhede deur die verbaal apraktiese sprekers het ook meestal die geheue van die digitale herhalingslyn, naamlik 2,5 sekondes, oorskry en dus meting van langer dele verhoed.

Die eerste metingspunt is die aanvang van die ploffing en die tweede punt is die laagste vlak wat bereik word by die afplatting van die kurwe van die tweede vokaal. Die KVK duur is ook gemeet vanaf die aanvang van die inisiële ploffer tot by die einde van die ploffing van die finale konsonant.

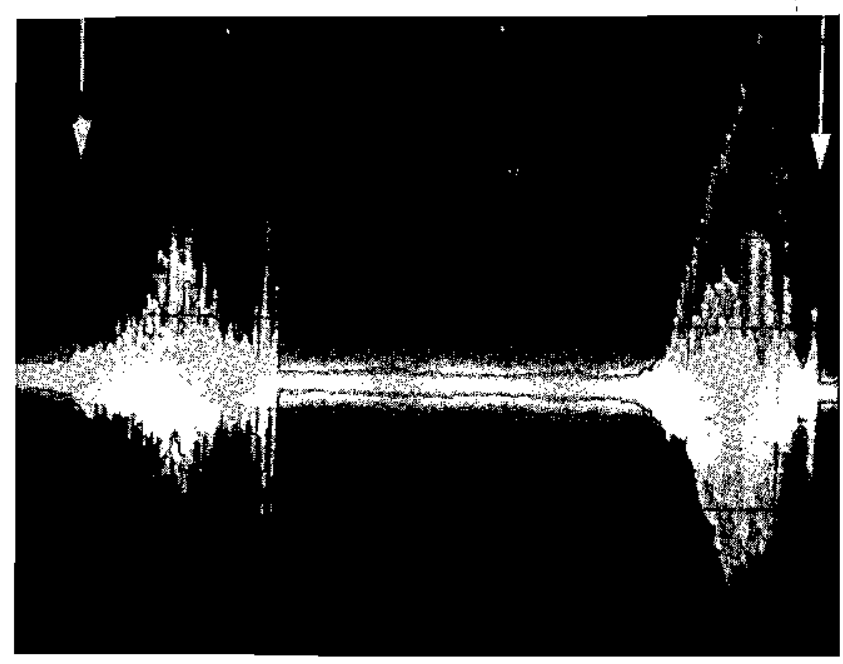

Uitingduur: 920 millisekondes

(Spoed: 120 millisekondes per divisie Duur van beeld: 1,2 sekondes)

Figuur 7: Voorbeeld van die uitingduur van 'n verbaal apraktiese spreker. 


\section{DATAVERWERKING}

Die stemaanvangstyd, vokaalduur en uitingduur van ses herhalings van die twintig eenhede wat akoesties ontleed is, is vir elke proefpersoon en kontrolepersoon verkry. Alvorens die invloed van die twee kontekstuele faktore bepaal kon word, is 'n gemiddelde foutwaarde vir elke persoon bereken. Die metode van berekening word vervolgens beskryf.

\section{Bepaling van die gemiddelde foutwaarde vir stemaanvangstyd}

Die stemaanvangstydwaardes van -180 millisekondes tot +15 millisekondes is aanvaar as die normale perke. In die literatuur word 'n positiewe telling van +25 millisekondes as die hoogste normale perk beskou. Daar is egter waargeneem dat by ' $n$ telling hoër as +15 millisekondes die klank reeds stemloos klink. Jansen (1985) beskou ook 'n telling hoër as +15 millisekondes as afwykend en daar is op hierdie waarde as die hoogste normale perk besluit. Die data van die kontrolepersone is dus nie vir hierdie spesifieke doel gebruik nie.

Verskeie metodes is oorweeg om 'n enkele stemaanvangstydwaarde wat die foutgrootte sal aandui oor ses herhalings, te bereken. Daar is volstaan deur' $n$ gemiddelde foutwaarde vir die ses herhalings van elke eenheid te bereken. Dit is gedoen deur die hoeveelheid millisekondes bokant 15 of onder 180 (laasgenoemde het nooit voorgekom nie) oor die ses herhalings bymekaar te tel en deur ses te deel. Hierdie gemiddeldes vir elke eenheid en vir elke proefpersoon word aangegee in tabel 1. Die klankstruktuurgroepe (S1 tot $\mathrm{S5}$ ) en die artikulasieeienskapgroepe (A1 tot A4) word in die tabel onderskei soos wat dit aangegee word in tabelle 2 en 3.

\section{Bepaling van die gemiddelde foutwaarde vir vokaalduur en uitingduur.}

Die gemiddelde foutwaarde (die mate van afwyking vanaf die normale) is op dieselfde wyse bepaal vir vokaalduur en uitingduur en dit word dus gesamentlik bespreek.

Die gemiddelde duur in millisekondes van die ses herhalings '́van elke eenheid by elke proefpersoon en kontrolepersoon is bereken. Die verskil tussen hierdie twee waardes wat die mate van afwyking vanaf die normale weergee, is bereken. Die waardes van die proefpersone was in alle gevalle groter as dié van die kontrolepersone behalwe by enkele KVK-uitings. Hierdie verskille in millisekondes word vir vokaalduur weergegee in tabel 4 en vir uitingsduur in tabel 5. Die klankstruktuurgroepe en artikulasie-eienskapgrope word ook in hierdie geval onderskei op die tabelle.

\section{Statistiese prosedure om te bepaal of klankstruktuur} en artikulasie-eienskappe enige effek het op stemaanvangstyd, vokaalduur en uitingduur.

Ten einde te bepaal of klankstruktuur en artikulasie-eienskappe enige effek het of SAT, vokaalduur en uitingduur, is die verdelingsvrye variansie-analiseprosedure van Friedman gebruik. Hierdie analise is toegepas op die waardes in die kolomme en rye van tabelle 1,4 en 5 . Die uiteensetting van die rye en kolomme van die tabelle is volgens die riglyne wat by die ontwikkeling van die materiaal bepaal is.

Deur middel van die Friedman-prosedure is vasgestel of die gemiddelde foutwaardes van die verskillende klankstruktuurgroepe (S1 totS5) of die verskillende artikulasie-eienskapgroepe (A1 tot A4) betekenisvol van mekaar verskil. Dit is globaal vir klankstruktuur en vir artikulasie-eienskappe bepaal en dit is ook vir die afsonderlike A- en S- groepe bepaal. Dit is essensieel om die invloed van klankstruktuur by elke artikulasiegroep afsonderlik te bepaal (dus vier vertikale vergelykings van die kolomwaardes in tabelle 1,4 en 5) aangesien die artikulasie- eienskappe van die uitings andersins ook 'n invloed op die waarde wat verkry word, sal uitoefen. Dit geld ook vir die bepaling van die effek van artikulasie-eienskapgroepe (in hierdie geval is vyf horisontale vergelykings van die rywaardes gedoen). Die invloed van die artikulasieeienskappe word dus by elke klankstruktuurgroep afsonderlik bepaal. Die P-waardes toon die betekenisvolheid van verskille aan.

\section{RESULTATE EN BESPREKING}

\section{RESULTATE VAN STEMAANVANGSTYDMETINGS}

\section{Algemene beskrywing en bespreking.}

Die meting van die stemaanvangstyd (SAT) van ses herhalings van twintig eenhede deur die verbaal apraktiese sprekers wat in hierdie ondersoek gebruik is, dui daarop dat afwykende

Tabel 1: Gemiddelde en totale stemaanvangstydfoutwaardes in millisekondes

\begin{tabular}{|c|c|c|c|c|c|c|c|c|c|c|c|c|c|c|c|c|c|c|c|c|c|}
\hline \multirow{3}{*}{$\begin{array}{l}\text { Klankstruktuur- } \\
\text { groepe }\end{array}$} & \multicolumn{21}{|c|}{ Artikulasie-eienskapgroepe } \\
\hline & \multicolumn{5}{|c|}{ A1 } & \multicolumn{5}{|c|}{$\mathrm{Az}$} & \multicolumn{5}{|c|}{ A3 } & \multicolumn{5}{|c|}{ A4 } & \\
\hline & 1 & 2 & 3 & 4 & 5 & 1 & 2 & 3 & 4 & 5 & 1 & 2 & 3 & 4 & 5 & 1 & 2 & 3 & 4 & 5 & \\
\hline \multirow{2}{*}{$\mathbf{S} 1$} & \multicolumn{5}{|c|}{ Eenhede: 1.1} & \multicolumn{5}{|c|}{1.2} & \multicolumn{5}{|c|}{1.3} & \multicolumn{5}{|c|}{1.4} & \\
\hline & 0 & 0 & 4 & 0 & 0 & 0 & 0 & 0 & 0 & 4 & 3 & 0 & 12 & 0 & 1 & 2 & 0 & 0 & 0 & 0 & 26 \\
\hline \multirow{2}{*}{$\mathrm{S} 2$} & \multicolumn{5}{|c|}{ Eenhede: 2.1} & \multicolumn{5}{|c|}{2.2} & \multicolumn{5}{|c|}{2.3} & \multicolumn{5}{|c|}{2.4} & \\
\hline & 1 & 0 & 1 & 0 & 1 & 3 & 0 & 2 & 0 & 1 & 1 & 0 & 24 & 0 & 1 & 9 & 0 & 9 & 0 & 1 & 54 \\
\hline \multirow{2}{*}{$\mathrm{S} 3$} & \multicolumn{5}{|c|}{ Eenhede: 3.1} & \multicolumn{5}{|c|}{3.2} & \multicolumn{5}{|c|}{3.3} & \multicolumn{5}{|c|}{3.4} & \\
\hline & 10 & 2 & 5 & 0 & 0 & 0,5 & 0 & 0 & 0 & 13 & 2 & 0 & 5 & 0 & 1 & 4 & 0 & 20 & 0 & 0 & 26,5 \\
\hline \multirow{2}{*}{ S4 } & \multicolumn{5}{|c|}{ Eenhede: 4.1} & \multicolumn{5}{|c|}{4.2} & \multicolumn{5}{|c|}{4.3} & \multicolumn{5}{|c|}{4.4} & \\
\hline & 5 & 1 & 0 & 0 & 3 & 1 & 0 & 0 & 0 & 0 & 5 & 0 & 11 & 4 & 0 & 4 & 0 & 11 & 0 & 0 & 45 \\
\hline \multirow[t]{2}{*}{$\dot{\mathrm{S} 5}$} & \multicolumn{5}{|c|}{ Eenhede: 5.1} & \multicolumn{5}{|c|}{5.2} & \multicolumn{5}{|c|}{5.3} & \multicolumn{5}{|c|}{$5.4^{\circ}$} & \\
\hline & 5 & 19 & 6 & 0 & & 2 & 0 & 0 & 0 & & 0,5 & 0 & 2 & 0 & 0 & 1 & 0 & $7^{:}$ & 0 & 0 & 42,5 \\
\hline Totaal & & & 63 & & & & & 26,5 & & & & & 27,5 & & & & & 68 & & & \\
\hline
\end{tabular}


stemaanvangstye (SATe) voorkom by die meeste van hierdie sprekers. (Kyk tabel 1 vir die gemiddelde SAT-foute in millisekondes vir elke eenheid en vir elke proefpersoon en tabelle 2 en 3 vir voorbeelde van gemete waardes.) Die resultate van hierdie studie stem in groot mate ooreen met die resultate van vorige ondersoeke na SAT by verbaal apraktiese sprekers en addisionele waarnemings is ook gemaak (Freeman et al. 1978; Blumstein et al. 1977; Hoit-Dalgaard, Murray \& Kopp, 1983; Itoh en Sasanuma, 1984; Kent en Rosenbek, 1983).

Tabel 2: Die gemete SAT-waardes van die ses herhalings van eenhede in die verskillende klankstruktuurgroepe in artikulasie-eienskapgroep 1

\begin{tabular}{|c|c|c|c|c|c|c|c|}
\hline $\begin{array}{l}\text { Proef- } \\
\text { persoon }\end{array}$ & $\begin{array}{l}\text { Uiting- } \\
\text { nommer }\end{array}$ & \multicolumn{6}{|c|}{ Gemete SAT-waardes van die ses herhalings } \\
\hline 1 & $\begin{array}{l}1.1 \\
2.1 \\
3.1 \\
4.1 \\
5.1\end{array}$ & $\begin{array}{r}0 \\
+14 \\
+18 \\
+15 \\
+10\end{array}$ & $\begin{array}{l}+11 \\
+10 \\
+15 \\
+20 \\
+11\end{array}$ & $\begin{array}{r}0 \\
+19 \\
+20 \\
+26 \\
+12\end{array}$ & $\begin{array}{r}0 \\
+14 \\
+36 \\
+15 \\
+13\end{array}$ & $\begin{array}{r}0 \\
+15 \\
+20 \\
+28 \\
+30\end{array}$ & $\begin{array}{r}0 \\
+18 \\
+40 \\
+8 \\
+32\end{array}$ \\
\hline 2 & $\begin{array}{l}1.1 \\
2.1 \\
3.1 \\
4.1 \\
5.1\end{array}$ & $\begin{array}{r}+6 \\
0 \\
+26 \\
+10 \\
+15\end{array}$ & $\begin{array}{r}0 \\
0 \\
+\quad 6 \\
0 \\
+120\end{array}$ & $\begin{array}{r}0 \\
-26 \\
+\quad 6 \\
+10 \\
+10\end{array}$ & $\begin{array}{r}-116 \\
0 \\
0 \\
+18 \\
+10\end{array}$ & $\begin{array}{l}-20 \\
+12 \\
+6 \\
+16 \\
+20\end{array}$ & $\begin{array}{r}-64 \\
0 \\
0 \\
+10 \\
+17\end{array}$ \\
\hline 3 & $\begin{array}{l}1.1 \\
2.1 \\
3.1 \\
4.1 \\
5.1\end{array}$ & $\begin{array}{r}+26 \\
0 \\
+12 \\
0 \\
+24\end{array}$ & $\begin{array}{r}+24 \\
0 \\
+10 \\
+5 \\
+34\end{array}$ & $\begin{array}{r}0 \\
+20 \\
+14 \\
0 \\
+10\end{array}$ & $\begin{array}{l}+20 \\
+10 \\
+40 \\
+16 \\
+12\end{array}$ & $\begin{array}{l}+10 \\
+10 \\
+20 \\
+5 \\
+16\end{array}$ & $\begin{array}{l}+16 \\
+7 \\
+10 \\
+10 \\
+22\end{array}$ \\
\hline 4 & $\begin{array}{l}1.1 \\
2.1 \\
3.1 \\
4.1 \\
5.1\end{array}$ & $\begin{array}{l}-60 \\
-84 \\
-48 \\
-40 \\
-68\end{array}$ & $\begin{array}{r}-60 \\
-60 \\
-10 \\
-72 \\
-136\end{array}$ & $\begin{array}{r}-40 \\
-80 \\
-132 \\
-60 \\
-12\end{array}$ & $\begin{array}{r}-36 \\
-60 \\
-100 \\
-60 \\
-68\end{array}$ & $\begin{array}{l}-20 \\
-40 \\
-36 \\
-10 \\
-80\end{array}$ & $\begin{array}{r}-80 \\
0 \\
-76 \\
-112 \\
-100\end{array}$ \\
\hline 5 & $\begin{array}{l}1.1 \\
2.1 \\
3.1 \\
4.1 \\
5.1\end{array}$ & $\begin{array}{r}+5 \\
+5 \\
+10 \\
20\end{array}$ & $\begin{array}{l}+10 \\
+9 \\
+12 \\
+10\end{array}$ & $\begin{array}{r}+9 \\
+20 \\
0 \\
0\end{array}$ & $\begin{array}{r}+5 \\
+10 \\
+12 \\
0 \\
\text { et } / t /\end{array}$ & $\begin{array}{r}+12 \\
+10 \\
0 \\
+\quad 7\end{array}$ & $\begin{array}{l}+10 \\
+10 \\
+11 \\
+7\end{array}$ \\
\hline
\end{tabular}

Tabel 3: Die gemete SAT-waardes van die ses herhalings van eenhede in die verskillende artikulasie-eienskapgroepe in klankstruktuurgroep 1.

\begin{tabular}{|c|c|rrrrrr|}
\hline $\begin{array}{c}\text { Proef } \\
\text { persoon }\end{array}$ & Uiting- & \multicolumn{7}{|c}{ Gemete SAT-waardes van die ses herhalings } \\
\hline 1 & 1.1 & 0. & +11 & 0 & 0 & 0 & 0 \\
& 1.2 & +10 & 0 & 0 & +10 & 0 & +9 \\
& 1.3 & +10 & +20 & +12 & +20 & +24 & +10 \\
& 1.4 & +10 & +18 & +10 & +11 & +12 & +24 \\
\hline 2 & 1.1 & +6 & 0 & 0 & -116 & -20 & -64 \\
& 1.2 & +6 & 0 & 0 & +6 & -34 & -70 \\
& 1.3 & 0 & 0 & -40 & 0 & +8 & 0 \\
& 1.4 & 0 & 0 & +6 & 0 & 0 & +6 \\
\hline 3 & 1.1 & +26 & +24 & 0 & +20 & +10 & +16 \\
& 1.2 & 0 & 0 & +10 & +12 & +12 & +12 \\
& 1.3 & +18 & +46 & +20 & +26 & +22 & +26 \\
& 1.4 & +16 & +14 & +14 & +10 & +12 & +10 \\
\hline 4 & 1.1 & -60 & -60 & -40 & -36 & -20 & -80 \\
& 1.2 & -80 & -48 & -80 & -80 & 0 & -80 \\
& 1.3 & -100 & -52 & -22 & -76 & -48 & 0 \\
& 1.4 & -64 & -60 & -48 & -100 & -80 & -52 \\
\hline 5 & 1.1 & +5 & +10 & +9 & +5 & +12 & +10 \\
& 1.2 & +6 & +20 & +20 & +20 & +20 & +18 \\
& 1.3 & +6 & +10 & +14 & +7 & +20 & +12 \\
& 1.4 & +6 & +14 & +8 & +6 & 0 & +10 \\
\hline
\end{tabular}

Freeman et al. (1978) wat 'n gevallestudie uitgevoer het, meld dat daar onder meer bepaal moet word of afwykende SAT ' $n$ algemene eienskap van verbale apraksie is en of die probleem idiosinkraties is. In die huidige ondersoek is bevind dat nie alle sprekers wat wel as verbaal aprakties geklassifiseer kan word, SAT-foute makk of in dieselfde mate maknie. Proefpersoon 2 het slegs by artikulasiegroep $1 \mathrm{en}$ in besonder by S5 SAT-foute gemaak (kyk tabel 1). Proefpersoon 4 het slegs by uiting 4.3 'n gemiddelde SAT-fout van vier. Verder vertoon hy geen SAT-foute nie. Die ander drie proefpersone mak wel SAT-foute. Die feit dat nie alle verbaal apraktiese sprekers SAT-foute maak nie, dui moontlik daarop dat interartikulatorsinchronisasie soos onder meer weerspieël in SAT, beheer word deur'n meganisme wat nie in alle verbaal apraktiese sprekers versteur is nie. Afwykende SAT is dikwels die residuele probleem van 'n verbaal aprakt iese spreker (Freeman et al. 1978). Hierdie gegewens impliseer dat selektiewe aantasting van temporale interartikulator-sinchronisasie kan voorkom en dui dus daarop dat hierdie komponent van beplanning moontlik onafhanklik funksioneer. Hoit-Dalgaard et al. (1983) noem dat SAT by verbale apraksie onvoorspelbaar is en ook Kent en Rosenbek (1983) meld dat die SAT-resultate van die individuele sprekers verskil. Hulle vind egter afwykings by al die sprekers. Die feit dat nie alle sprekers in hierdie studie SAT-foute vertoon nie, kan ook daarop dui dat verskillende tipes verbale apraksie voorkom, met selektiewe aantasting van komponente van motoriese beplanning.

Die SAT-foute wat waargeneem is, is in alle gevalle té groot positiewe SAT tellings van +15 millisekondes of meer vir stemhebbende klanke (kyk tabelle 2 en 3 vir voorbeelde). Die positiewe telling is die gevolg van 'n verlengde stemnalooptyd. SAT-tellings van meer as +15 millisekondes bring mee dat die klank as stemloos waargeneem word. Die materiaal sluit slegs stemhebbende klanke in en afleidings kan dus slegs hieroor gernaak word. In die literatuur word gerapporteer dat stemhebbende klanke meer algemeen stemloos gemaak word as wat stemlose klanke stemhebbend gemaak word (Wertz et al. 1984: 52).

Die waarneming dat stemhebbende klanke té groot positiewe tellings oplewer van ongeveer +15 tot +30 millisekondes, bevestig die resultate van ander studies (Freeman et al. 1978; Blumstein et al. 1977). Daar is verder ook bevind dat slegs 17 van die 600 uitings (dus $2,8 \%$ ) positiewe tellings van 35 milli: sekondes of meer getoon het. 'n Stemlose, bilabiale plosief se SAT is +35 tot +150 millisekondes (Blumstein et al. 1977). ' $n$ Ware stemlose klank is dus slegs in 'n minimum van die gevalle geproduseer. Freeman et al. (1978) het gevind dat daar 'n oor' vleueling in die SATe van stemhebbende en stemlose klanke voorkom en dat ook stemlose klanke dus nie volkome korrek: geproduseer word nie.

Die té groot positiewe tellings wat waargeneem is, impliseer op 'n gedragsvlak dat die glottale sluiting temporaal vertraag is in verhouding tot die verbreking van die afsluiting deur die artikulators. Daar is verskillende moontlike verklarings vir die verlengde stemnalooptyd of anders gestel, die vertraagde inisiëring van stemgewing wat voorkom by verbaal apraktiese sprekers. Vanuit die oogpunt van die bekende regressieteorie wat ook soms op verbale apraksie toegepas word (Márquardt, Reinhart \& Peterson, 1979) kan daar gepoog word om hierdie verskynsel te verklaar as moontlike regressie na 'n infantiele vorm van spraakproduksie. Volgens Kewley-Port en Preston (1974) dek die SATe van beide stemhebbende en stemlose klanke 'n wye omvang by kinders op'n leeftyd van ses maande. Daarna volg ' $n$ periode waarin die SAT vir stemhebbende en 
stemlose klanke net tussen 0 en +20 millisekondes is. Stemvoorlope kom glad nie voor nie. Volgens bogenoemde outeurs en Cooper (1977) wat die teorie ondersteun, is dit motories maklik om 'n stemhebbende klank met'n kort $(0-+20$ millisekondes) nalooptyd te produseer. Die ploffing lei tot 'n afname in lugdruk wat die stembande dan in staat stel om spoedig na die ploffing te begin vibreer. 'n Lang stemnalooptyd vir stemlose klanke vere is volgens hul verklaring 'n addisionele neurale bevel en is dus moeiliker om te produseer. Oppervlakkig beskou, verklaar hierdie ontwikkelings-teorie nie die groot positiewe tellings ( +15 tot +35 millisekondes) nie want daarvolgens neig die verbaal apraktiese sprekers om stemhebbende klanke motories moeiliker te maak.

Die belangrike punt wat hier in gedagte gehou moet word, is dat stemgewing soms in terme van die norm te laat 'n aanvang neem of geinisieer word vir die korrekte produksie van 'n stemhebbende klank. Dit sou dus sinvol wees om aandag te skenk aan die neurale inisiëring van stemgewing en gegewens in hierdie verband na te gaan vir moontlike verklarings. Glottale bewegings geskied sonder die bewussyn van die normale spreker maar daar is wel neuro-anatomiese (Jürgens \& Ploog, 1981; Ploog, 1981), neuropatologiese (Jürgens \& Von Cramon, 1982) en neurofisiologiese (Aitken \& Wilson, 1979) gegewens wat aandui dat fonasie willekeurig beheer word. Die fonasiekontrolestelsel is hiërargies georganiseerd en die hoogste vlak is gesetel in die anterior limbiese korteks (Ploog, 1981). Skynbaar speel ander strukture wat essensieel is vir artikulasie (byvoorbeeld die sensories-motoriese korteks, talamus en serebellum) nie 'n rol by stemgewing nie (Jürgens \& Ploog, 1981). Die feit dat die limbiese stelsel wat' $n$ rol speel by inisiëring van motoriek (Mogeson, Jones \& Yim, 1980) ook willekeurige stemgewing beheer, is in die lig van die feit dat verbale apraksie beskryf word as 'n afwyking in willekeurige beweging, belangrik. Moontlik kan'n versteuring in die meganisme van willekeurige inisiëring deur die limbiese stelsel, of versteurde interaksie met ander motoriese dele, die afwyking in temporale sinchronisasie en wel die vertraagde inisiëring van stemgewing verklaar.

Dit is insiggewend dat geen stemvoorlope waargeneem is by die drie proefpersone wat SAT-foute gemaak het nie. Hierdie jevinding bevestig die resultate van Freeman et al. (1978). Antisiperende stemgewing het dus glad nie voorgekom nie, maar slegs vertraagde stemgewing.

Vanuit ' $n$ ander perspektief (wat nie teenstrydig is met die verklaring hierbo nie, maai dit wel aanvul) kan die temporale sinchronisering van artikulatoriese beweging met glottale sluiting, as 'n motoriese dóelwit wat die spreker moet bereik, beskou word. Die ossilloskoopbeeld wat verkry is (wat moontlik gemaak word deur die besondere apparaat wat gebruik is) by proefpersone 3 en 5 werp moontlik verdere lig op temporale sinchronisering as 'n motoriese doelwit. By beide hierdie persone was daar in uitings met hoë positiewe SAT-tellings, aanduidings dat ploffing en stemgewing onafhanklik plaasvind en nie geīnttgreera is nie. Die plorfing het in baie gevalle gepaard gegaan met baie ruising wat soms verleng was en dan 'n onafhanklike aanvang van stemgewing. Dit wil voorkom asof daar 'n bewustheid by hierdie twee verbaal apraktiese sprekers is van die twee komponente van die uiting, naamlik ploffing en stemgewing. Daar is dus aanduidings van kennis van die komponente van die motorprogram, maar daar ontstaan blykbaar 'n probleem in die vooruitvoering daarvan. Die probleem kan die vertraagde inisiëring van stemgewing wees of die onafhanklike vooruitvoering van subroetines van bewegings. Die temporale sinchronisering van spraakbewegings het egter kritiese temporale ekwivalensiegrense en die onafhanklike of vertraagde inisiëring van subroetines van bewegings bring mee dat temporale wanpassing plaasvind met gevolglike distorsiefoute. Die kritiese grense van temporale interartikulatorsinchronisasie is in groot mate onveranderlik en dit stel 'n hoë eis aan die spreker om die sinchronisasie wat binne millisekondes moet plaasvind, te beheer in vinnige opeenvolging. So 'n uitgangspunt verklaar ook deels die onkonstantheid in produksie wat ook waargeneem is.

'n Belangrike implikasie van die onkonstant foutiewe stemgewing is dat dit ' $n$ baie sterk aanduiding is dat dit onwaarskynlik is dat die vervangings met stemlose klanke die gevolg is van foutiewe klankseleksie of foutiewe ouditiewe persepsie van stemhebbendheid. Dit is aan die ander kant 'n baie sterk aanduiding dat stemhebbend-stemlose klankvervangings die gevolg is van afwykende beheer van die produksie van stemhebbende klanke. Veranderlikheid of onkonstantheid in die verskillende komponente van ' $n$ beweging is ' $n$ kenmerk van motoriek en ook spraakmotoriek. Die mate van veranderlikheid neem af tydens ontwikkeling totdat 'n volwasse stadium bereik word wanneer bewegings steeds veranderlik is, maar binne die grense van motoriese ekwivalensie (Turvey, Fitch \& Tuller, 1982; Kelso et al. 1983: 145). Die afleiding kan dus gemaak word dat onkonstantheid in die bewegingspesifikasies, byvoorbeeld in temporale inter-artikulator sinchronisasie, 'n aanduiding is van 'n motoriese probleem en nie 'n afwyking in die fonologiese kennis van fonotaktiese reëls nie. Kennis van die toepaslikheid van 'n spesifieke foneem en die ouditiewe herkenning daarvan is waarskynlik meer stabiele vermoëns wat berus op verworwe reëls en is nie wisselend van moment tot moment nie.

Afleidings gegrond op 'n enkele produksie van 'n klank is dus nie verteenwoordigend van die ware vermoë of onvermoë van die verbaal apraktiese spreker nie. 'n Enkele produksie van 'n stemhebbende klank wat toevallig stemloos klink, kan die lu isteraar mislei en meebring dat die afwyking geïnterpreteer word as 'n klankvervanging en dus afwykende klankseleksie wat aanduidend kan wees van 'n fonologiese beplanningsprobleem. 'n Interessante bevinding wat die uitgangspunt in hierdie studie bevestig, is dat die SATe slegs in $2,8 \%$ van die uitings die waardes van ware stemlose klanke, naamlik +40 millisekonde en hoër (Cooper, 1977) bereik het. Die "ververvangings" met klanke wat stemloos klink, is dus nie ware vervangings nie maar wel distorsie van die klanke.

'n Verdere insiggewende bevinding is dat die SAT-resultate van die proefpersoon met verbale ontwikkelingsapraksie volkome ooreenstem met die resultate van die ander proefpersone. Proefpersoon 5 het ook onkonstant SAT-foute gemaak en hy het die SAT-kenmerke vertoon wat ooreenstem met die patroon van proefpersoon 3. Dit wil dus voorkom asof dieselfde meganisme versteur word by kongenitale en verworwe breinskade wat aanleiding gee tot verbale apraksie.

Opsommend kom die SAT-resultate daarop neer dat afwykings nie in dieselfde mate by alle proefpersone voorkom nie; dat die SAT- foute die vorm aanneem van hoë positiewe tellings van +15 tot +35 millisekondes; dat SAT onkonstant foutief is en dat die resultate van die proefpersoon met verbale ontwikkelingsapraksie ooreenstem met die resultate van die ander proefpersone. Die SAT-foute word onvoldoende verklaar deur die regressieteorie of 'n teorie warin die foute aan ware klankvervangings of persepsieprobleme toegeskryf word. Die resultate word meer sinvol verklaar as 'n onvermoë om interartikulator- sinchronisasie binne die kritiese grense 
van temporale ekwivalensie te beheer en die bewegings temporaal georden vinnig te inisieer en geïntegreerd vooruit te voer.

Die invloed van die klankstruktuur van 'n uiting op stemaanvangstyd.

Ten einde te bepaal of variasie in die klankstruktuur van 'n uiting 'n effek het op die stemaanvangstyd van inisiële stemhebbende konsonante by verbaal apraktiese sprekers, is ' $n$ tweerigting-variansie-analise toegepas op die gemiddelde SATfoute van eenhede uit die verskillende klankstruktuurgroepe. Die eenhede vanuit die verskillende artikulasie-eienskapgroepe is afsonderlik vergelyk. 'n P-waarde van kleiner as 0,0125 dui daarop dat daar betekenisvolle verskille (op die $5 \%$ peil van betekenis) tussen die gemiddelde foute van die eenhede voorgekom het. Die P-waardes is almal groter as 0,0125 wat aandui dat daar geen betekenisvolle verskille tussen die gemiddelde SAT- foute in die verskillende klankstruktuurgroepe is nie.

Die feit dat SAT nie beteken isvolle sensitiwiteit vertoon vir die klankstruktuur van 'n uiting nie, kan 'n aanduiding wees dat die beheer van SAT' 'n suiwer motoriese gebeure is. Die motoriese prosesse wat nodig is om SAT te beheer, vertoon dus 'n afwyking ongeag die uiting waarin dit moet plaasvind. Die onkonstantheid in die SAT-foute het reeds gedui op hierdie moontlikheid. Dit wil dus op grond van hierdie ontleding voorkom asof SAT nie konteks-sensitief is nie en 'n suiwer motoriese komponent van die afwyking in verbale apraksie vorm. Die afwesigheid van konteks-sensitiwiteit dui moontlik ook daarop dat afwykings in SAT' $n$ kernsimptoom van verbale apraksie weerspieël.

\section{Die invloed van die artikulasie-eienskappe van 'n uiting op stem- aanvangstyd.}

Ten einde te bepaal of variasie in die artikulasie-eienskappe van uitings met dieselfde klankstruktuur enige effek het op SAT, is 'n tweerigting-variansie-analise uitgevoer op die gemiddelde SAT- foute van eenhede uit die verskillende artikulasie-eienskapgroepe.

Alle P-waardes is bokant 0,0125 wat impliseer dat daar geen betekenisvolle variasie tussen die uitings in die verskillende artikulasie-eienskapgroepe is nie.

Die afleiding gegrond op hierdie analise is dus dat SAT nie sensitief is vir die verskillende artikulasie-eienskappe wat in die materiaal teenwoordig is nie. Dit wil dus voorkom asof die afwyking in interartikulator-sinchronisasie vir SAT by die verbaal apraktiese spreker voorkom ongeag die artikulasie- of klankstruktuur-eienskappe van die uiting. Foute kom egter nie tydens elke uiting voor nie. Die verbaal apraktiese spreker het skynbaar 'n probleem om hierdie aspek van spraakbewegings te beheer.

\section{RESULTATE VAN VOKAALDUURMETINGS.}

\section{Algemene beskrywing en bespreking.}

Wisselende grootte verskille tussen die gemiddelde vokaalduur van ses herhalings van die verbaal apraktiese sprekers en normale sprekers is waargeneem. Hierdie verskille in millisekondes word aangegee in tabel 4.

Dit is insiggewend dat daar by sommige eenhe de geen verskille waargeneem is nie. Die uitings van die verbaal apraktiese sprekers was selfs in enkele gevalle 'n paar millisekondes korter as dié van die normale sprekers en die verskil word dan as nul aangegee. Tydens die verwerking van die data is ook waargeneem dat indien die langste duur van die ses herhalings van die normale sprekers in berekening gebring word, daar kleiner verskille veral by S4 voorkom.

Dit is ook interessant dat daar groot verskille bestaan tussen die mate waarin die individuele sprekers afwyk van die normale sprekers. Proefpersoon 4 vertoon die grootste mate van afwyking. Hy het ook by die SAT-metings anders gereageer as die ander vier proefpersone en dit wil dus voorkom asof hierdie spreker wat tog as verbaal aprakties gediagnoseer kan word, moontlik'n ander tipe aantasting vertoon. Proefpersone 1 en 5 vertoon die kleinste mate van afwyking ten opsigte van vokaalduur. Die proefpersoon met verbale ontwikkelingsapraksie vertoon wel ook verlengde vokaalduur soos die ander proefpersone.

Dit is belangrik om daarop te wys dat alhoewel daar individuele verskille voorkom, die orde van die foute by die verskillende eenhede, ooreenstemming toon. Die faktore wat in die materiaal gemanipuleer is, het dus 'n ooreenstemmende uitwerking op al die proefpersone. Die foutgrootte by $\$ 4$ is byvoorbeeld kleiner as by die ander strukture vir al die proefpersone. Dit kom dus voor asof daar 'n gemeenskaplike probleem by die sprekers aanwesig is alhoewel individuele verskille voorkom.

In die literatuur word oor die algemeen gerapporteer dat verlengde vokaalduur voorkom by die verbaal apraktiese spreker en dat dit'n komponent is van algemene artikulasieverlenging wat kenmerkend is van hierdie sprekers (Freeman et al. 1978; Collins et al. 1983; Kent \& Rosenbek 1983). Die mate van afwyking word nie aangegee nie en die struktuur van die uitings is ook nie gekontroleer nie. Kent en Rosenbek (1983) meld wel dat die duur toeneem namate die lengte van die uiting toeneem. Duffy en Gawle (1984) het vokaalduur in KVKuitings ondersoek en het ook vokaalduur korter as die normale waargeneem. Die moontlikheid bestaan dat die wisselende grootte foute wat in die huidige studie waargeneem is, verband hou met die variasie in die klankstruktuur en artikulasieeienskappe van die uiting. Die resultate van die ondersoek in hierdie verband word vervolgens verskaf.

Die invloed van die klankstruktuur van 'n uiting op vokaulduur.

Ten einde te bepaal of die klankstruktuur van 'n uiting 'n effek het op vokaalduur, is 'n tweerigting-variansie-analise uitge voer op die data wat aangegee word in tabel 4. Globaal gesien is daar uitgesproke betekenisvolle verskille tussen die mate van afwyking in vokaalduur van die eenhede in die verskillende klankstruktuurgroepe. ' $\mathrm{P}$-waarde van 0,0000 is verkry. Op grond van die beskikbare data kan die gevolgtrekking gemaak word dat die klankstruktuur van 'n uiting 'n effek het op die vokaalduur. Vokaalduur vertoon dus konteks-sensitiwiteit.

Die betekenisvolle verskille wat hier waargeneem is, is tussen die vokaalduur van klankstruktuur 4 en die ander klańkstrukture. Die verskille tussen die ander klankstrukture is statisties nie betekenisvol nie. Verbaal apraktiese sprekers vertoon feitlik normale vokaalduur in KVK-uitings. Verlengde segmentele duur is dus nie 'n primêre eienskap van verbaal apraktiese spraak nie (Duffy \& Gawle, 1984; Rosenbek, Kent \& La। Pointe, 1984: 16). Die mate van afwyking in vokaalduur het 
Invloed van Sekere Kontekstuele Faktore op Stemaanvangatyd, Vokaalduur en Uitingduur

Tabel 4: Die verskil in millisekondes tussen die gemiddelde vokaalduur van die proefpersoon en die gemiddelde vokaalduur van die kontrolepersoon

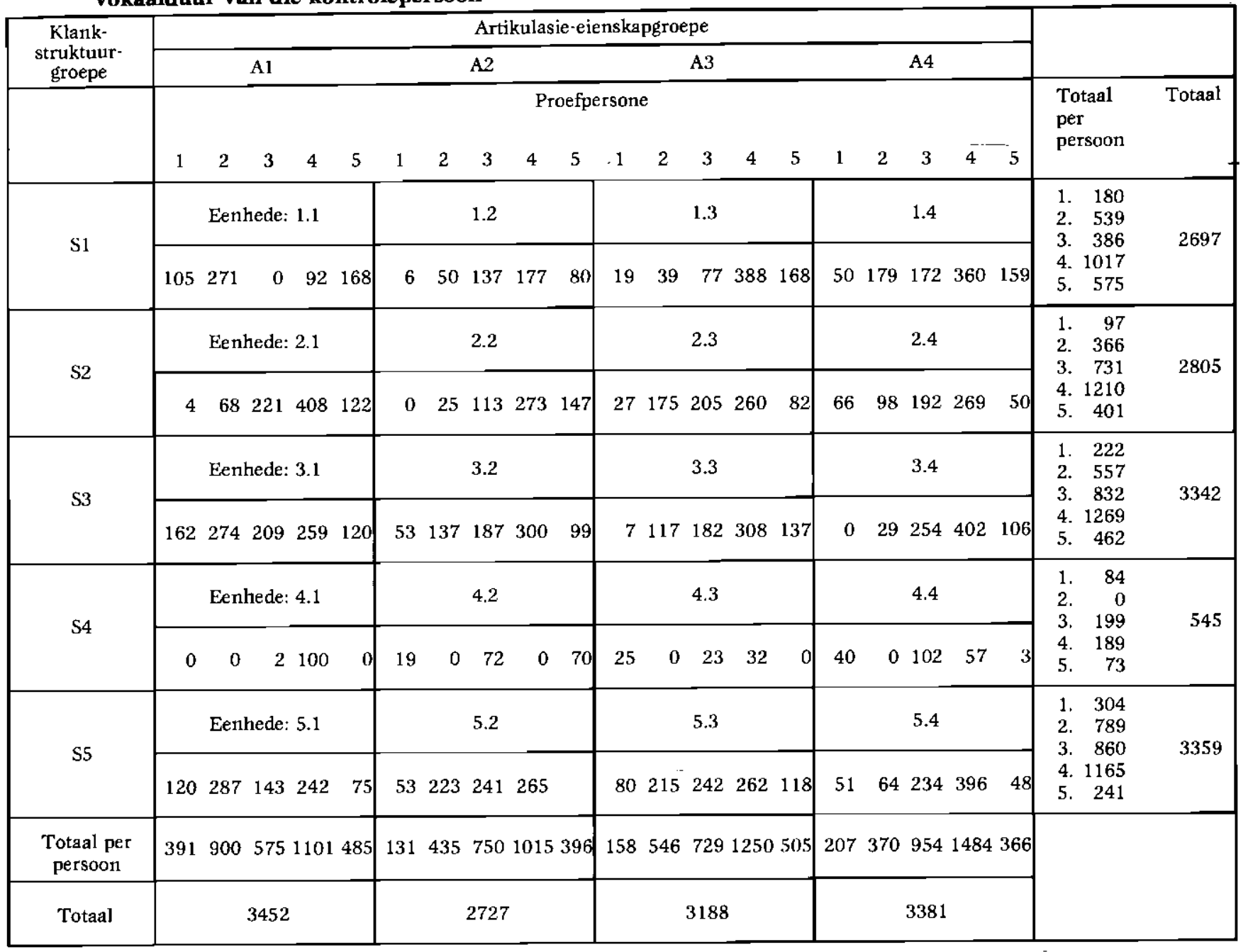

toegeneem namate die lengte van die uiting toegeneem het (kyk tabel 4). Dit kom dus voor asof die spreker segmentele duur verleng in langer eenhede wat hoër eise stel aan sy spraakproduksievermoë. Dit word algemeen aanvaar dat lańger uitings lei tot meer spraakfoute by die verbaal aprak'tiese spreker (Rosenbek et al. 1984:15; Kent \& Rosenbek, 1983). Die resultate van hilerdie studie bevestig dus hierdie aanname. Dit beantwoord ook in groot mate die vraag of verlengde artikulasie 'n direkte gevolg is van die neuromotoriese afwyking (Kent, Netsell \& Abbs, 1979). Op grond van die huidige resultate skyn dit nie die geval te wees nie. Verlengde segmentele duur is meer waarskynlik 'n kompensatoriese strategie om die onderliggende neuromotoriese probleem te oorkom.

Die resultate impliseer verder ook dat die Engelssprekende verbaal apraktiese sprekers (dit is nie bekend of die reël ook geld in Afrikaans nie) sensitiwiteit behou vir die linguistiese reël dat vokaalduur verkort voor' $n$ plosief in die finale posisie van ' $\mathrm{n}$ woord (Duffy \& Gawle, 1984: 169). Dit word weerspieël deur die feitlik normale vokaalduur wat waargeneem is by die KVK-eenhede wat almal plosiewe klanke in die finale posisie het. Alhoewel dit meestal onsineenhede was, het dieselfde reël wat verwag word by betekenisvolle spraak by beide groepe (eksperimenteel en kontrole) sprekers in werking getree. Die resultate van Collins et al. (1983) wat die be houd van 'n reël vir duurverhoudinge waargeneem het, word dus bevestig. Collins et al. (1983) het bevind dat al hoewel vokaalduur verleng is, die duur wel soos by die normale spreker verkort word namate die lengte van die woord waarin dit voorkom, toeneem. Hul afleiding is dat die verbaal apraktiese spreker sensitiwiteit vir hierdie vlak van "fonologiese enkodering" behou. Die spreker beskik dus nog oor die nodige kennis van linguistiese reëls. Die verskynsel dat vokaalduur verkort voor 'n stemlose plosief is 'n aangeleerde eienskap wat nie voorkom in die spraak van driejariges nie (DiSimoni, 1974). Die feit dat hierdie verskynsel waargeneem word in die spraak van verbaal apraktiese sprekers is ' $n$ verdere aanduiding dat die probleem nie bloot' $n$ regressie na' $n$ infantiele spraakproduksiewyse is nie.

Die invloed van die artikulasie-eienskappe van'n uiting op vokaalduur.

Geeneen van die berekende P-waardes is onder 0,0125 nie, wat impliseer dat daar geen betekenisvolle verskille tussen die mate van afwyking in vokaalduur van eenhede in die verskillende artikulasiegroepe is nie. Groot waardes is oor die algemeen verkry. Die artikulasie-eienskappe wat in die materiaal gedek is, het dus geen statisties beduidende effek op die vokaalduur nie. Die gegewens in tabe 4 toon egter aan dat die mate van afwyking van $\mathrm{A} 1$ en $\mathrm{A} 2$ meer verskil as wat byvoorbeeld $\mathrm{A} 1$ en A4 verskil. Al vertoon die grootste mate van afwyking in vokaalduur en A2 die kleinste. Daar is dus aanduidings dat eenhede met verskillende artikulasie-eienskappe nie homogene eise stel aan die spraakproduksievermoë van die verbaal apraktiese sprekers nie. Ten einde duplisering te beperk sal die implikasies van hierdie gegewens bespreek word tydens die bespreking van die invloed van artikulasie-eienskappe op uitingduur. 
Tabel 5: Die verskil in millisekondes tussen die gemiddelde uitingduur van die proefpersoon en die gemiddelde uitingduur van die kontrolepersoon

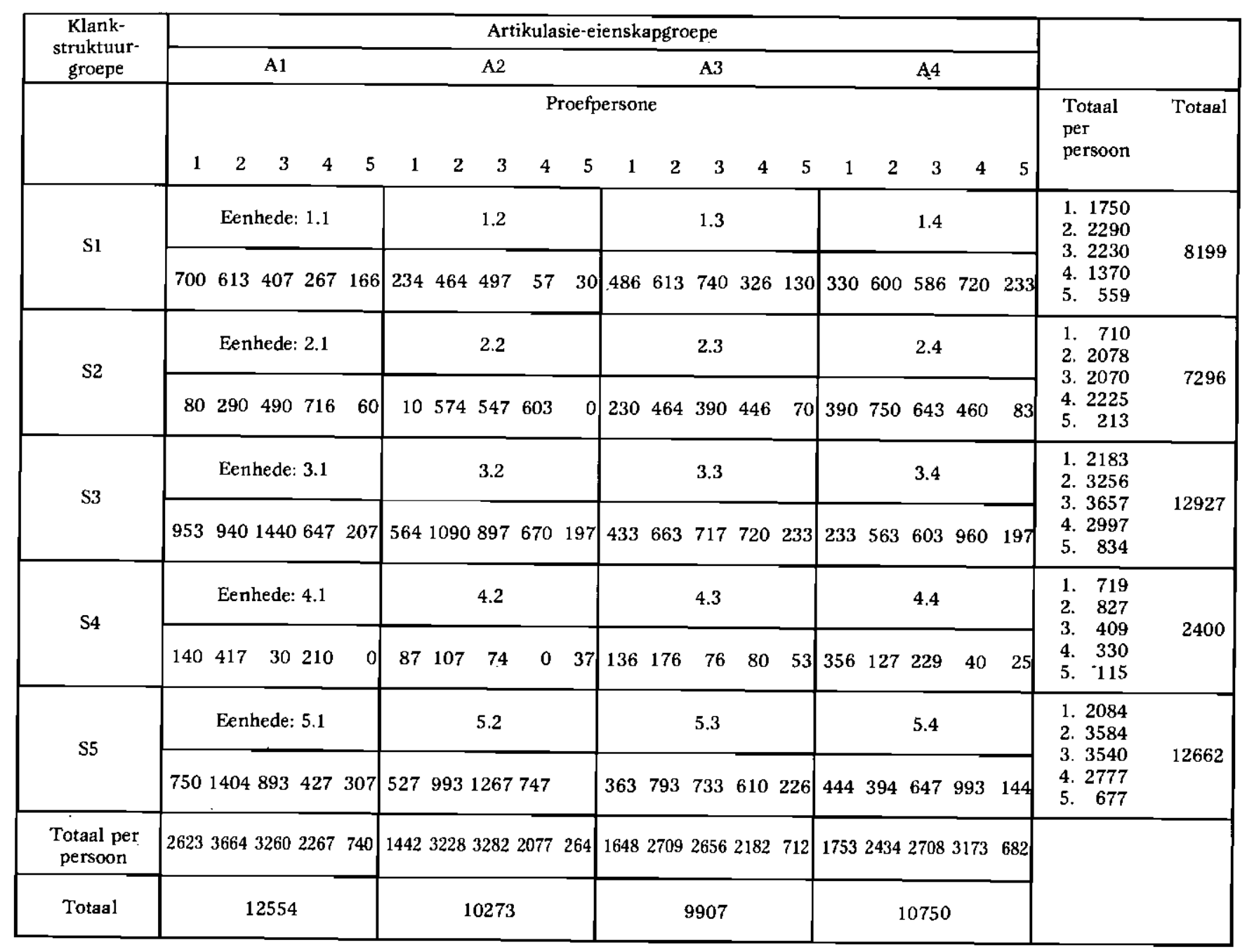

\section{RESULTATE VAN UITINGDUURMETINGS.}

\section{Algemene beskrywing en bespreking.}

Die verskil in millisekondes tussen die gemiddelde uitingduur van die proefpersone en die kontrolepersone word weergegee in tabel 5. Die groot verskille wat waargeneem is, impliseer dat al die proefpersone stadige spraakspoed vertoon. Volgens die meeste navorsers is stadige spraakspoed kenmerkend van die verbaal apraktiese spreker (Wertz et al. 1984: 71; Kent \& Rosenbek, 1983; Rosenbek et al. 1984: 15).

Die grootste verskille tussen die gemiddelde uitingduur van normale en verbaal apraktiese sprekers ten opsigte van klankstruktuurgroepe kom voor by S3 en S5. Daarna volg S1 en S2 en die kleinste verskil is by $\mathrm{S} 4$. Wat die verskillende artikulasieeienskapgroepe betref, kom daar ook verskille voor wat groter is as die verskille wat ten opsigte van artikulasie-eienskapgroepe by die vokaalduurmetings waargeneem is (kyk tabel 4).

Wat die individuele proefpersone aanbetref, word bemerk dat proefpersoon 4 nie soos in die geval van vokaalduur die grootste afwyking vertoon nie. Dit is ' $n$ interessante verskynsel, want dit impliseer dat segmentele duur meer verleng is as by die ander sprekers, maar die oorgange van een klank na ' $n$ ander vind dus vinniger plaas. 'n Verdere interessante waarneming is dat proefpersoon 5 sonder uitsondering die kortste uitingduur van al die proefpersone yertoon. Dit was egter nie die geval by vokaalduur nie (kyk tabel 4) alhoewel daar ook 'n neiging tot 'n vokaalduur korter as die gemiddelde waargeneem is. Die oorgange tussen klanke vind dus by proefpersoon 5 vinniger plaas as by enige van die ander proefpersone. Proefpersoon 5 wat 'n verbale ontwikkelingsapraksie vertoon, was nie-verbaal tot op onge: veer vierjarige ouderdom en het daarna met behulp van die Terapieprogram vir verbale ontwikkelingsapraksie (van der Merwe, 1985) spraakproduksie aangeleer oor 'n tydperk van ongeveer vier jaar. 'n Moontlike verklaring vir die vinniger spraakspoed is dat alle spraak wat hy vertoon doelbewus aangeleer is. Een van die grondbeginsels van die terapieprogram is die doelbewuste herhaalde produksie van eenhede met toenemende spoed. Die proefpersoon het dus 'n bewustelik aangeleerde motorprogram vir alle klanke en is geleer om dit herhaaldelik willekeurig te herroeop in alle klankomgewings en in langer wordende uitings. 'n Mate van outomatisasie het waarskynlik plaasgevind. Die ander proefpersone moet moontlik in 'n groter mate spraak wat voorheen outomaties plaasgevind het, doelbewus herroep, inisieer en beheer. Dit kan die gevolg wees van die effek van verworwe breinskade nadat spraak reeds aangeleer is en die reaksie daarop. Dit kan andersyds ook toegeskryf word aan die feit dat die vier volwassenes vir korter periodes dieselfde tipe behandeling as proefpersoon 5 ontvang het en tydens die ondersoek 
nog stadige spraak en stadige inisiëring vertoon het. Die gebrekkige outomatisasie van spraak verklaar moontlik die stadiger spraakspoed wat veral in die oorgange tussen klanke voorkom. Die afleiding kan dus nie sonder meer gemaak word dat kinders met verbale ontwikkelingsapraksie vinniger spraakspoed vertoon (indien hulle wel spraak kan produseer) as gevalle met verworwe verbale apraksie nie omdat die vermoëns waaroor proefpersoon 5 beskik deur middel van hierdie spesifieke benadering aan hom geleer is.

Dit is belangrik om daarop te wys dat proefpersoon 5 se spraak steeds stadiger is as normaal en dat die konteks van die uiting dieselfde uitwerking op sy spraakspoed het as op die spraakspoed van die persone met verworwe verbale apraksie. Die mate van afwyking is die grootste by S3 en S5. Daarna volg S1 en $S 2$ wat in mindere mate ' $n$ afwyking vertoon. Die geringste uitval is by $\mathrm{S} 4$.

Met betrekking tot spraakspoed vertoon die verbaal apraktiese spreker wel oppervlakkig geoordeel regressie. Daar is eksperimenteel bevind dat woordduur by die jong kind langer is as by die ouer kind en die volwassene (Kubaska \& Keating, 1981). Die onderliggende redes hiervoor kan egter verskil. Motoriese vaardigheid in die manipulasie van die spraakstrukture speel onder meer ' $n$ rol by spraakspoed en die jong kind kan moontlik weens beperkte vaardigheid spraak stadiger produseer. Stadige spraakspoed is ook kenmerkend van disartrie en in hierdie geval word spoed beperk weens versteurde spiertonus en onwillekeurige bewegings. 'n Verlaging in spraakspoed kan ook kompensatories wees of weens gebrekkige outomatisasie. Daar is dus verskillende redes vir stadige spraakspoed en dit is 'n oppervlakkige afleiding indien aanvaar word dat die stadige spraakspoed'n simptoom van regressie na'n infantiele spraakproduksiewyse is.

Opsommend kom die; resultate daarop neer dat die verbaal apraktiese sprekers wat in hierdie studie ondersoek is, stadige spraakspoed vertoon wat wissel in die mate waarin dit af wyk van normale spraakspoed. Die rol van variasie in die konteks van die uiting by die wisselende mate van afwyking, word vervolgens bespreek.

\section{Die invloed van die klankstruktuur van 'n uiting op uitingduur}

Die berekende P-waardes toon aan dat daar beduidende verskille voorkom tussen die mate van afwyking in uitingduur van eenhede in die verskillende klankstruktuurgroepe. Slegs by artikulasiegroep 4 het daar nie 'n beduidende verskil voorgekom tussen die klankstruktuurgroepe nie.

Die verskille wat waargeneem is, was tussen die eenhede in $\mathrm{S} 4$ en dié in S3 en S5. Betekenisvolle verskille is nie uitgewys tussen S4 en S1 en \$2 nie, maar die numeriese totaalwaardes in tabel 5 toon tog aan dat S1 en S2 nie dieselfde invloed het op uitingduur as die ander strukture nie. Dieselfde groepverdeling is waargeneem by vokaalduur (kyk tabel 4). Die gevolgtrekking is dus dat die klankstruktuur van 'n uiting 'n invloed het op die mate van afwyking in uitingduur.

'n Interessante verskynsel wat deur hierdie resultate aan die lig kom, is dat die byvoeging van 'n enkele klank by die klankstruktuur, meebring dat die produksie van die uiting meer problematies word vir die verbaal apraktiese sprekers. Klankstruktuur 4 wat die minste foute tot gevolg gehad het (by alle akoestiese analises) het 'n KVK-struktuur terwyl klankstrukture 1 en 2 wat die tweede groep vorm'n KVKV-struktuur het.
Daarteenoor het klankstrukture 3 en 5 wat die derde groep vorm onderskeidelik'n KVKVK-en KVKVKVK-struktuur. Die effek wat die byvoeging van 'n enkele klank het, is verrassend omdat die KVKV-struktuur byvoorbeeld slegs die byvoeging van 'n vokaal meebring. Artikulatories gesproke vereis dit weinig addisionele artikulasiebewegings na die verbreking van die afsluiting vir die finale plosief. Fonologies gesproke is dit'n klankstruktuur wat baie vroeg reeds in die spraak van die jong kind voorkom en die fonologiese beplanning van so'n uiting behoort nie meer problematies te wees as die KVK-struktuur nie. ' $n$ Verklaring vir hierdie verskynsel word dus nie vanuit hierdie oogpunte verkry nie.

'n Ander moontlike verklaring is dat die beplanning van 'n langer uiting meer kompleks is en meer tyd in beslag neem. Klapp, Anderson en Berrian (1973) het-deur middel van 'n reaksietydstudie bevind dat dit langer neem om 'n tweelettergrepige woord te beplan as wat dit neem om 'n eenlettergrepige woord te beplan. Die afleiding is dat dit langer neem om 'n meer komplekse motorprogram te beplan. Die data in die huidige studie toon aan dat langer eenhede langer neem om te produseer. Die feit dat korter eenhede teen feitlik normale spoed geproduseer word impliseer dus dat daar nie 'n primêre motoriese probleem is wat lei tot stadige spraakspoed nie. Dit is dus die beplanning van die langer uiting wat soveel meer tyd in beslag neem en nie die produksie daarvan nie.

Die moontlikheid bestaan ook dat die langer uiting op 'n ander wyse beheer word as die korter uiting wat minder kompleks is. Die verbaal apraktiese spreker kan moontlik vanweë die verhoogde eise van 'n langer uiting, dit nie volledig beplan voor produksie nie en moet dan voortdurend tydens produksie beplan. Schmidt (1982: 207) meld onder meer dat motories vaardige persone lang reekse bewegings vooraf kan beplan. Die teenoorgestelde is dus moontlik, naamlik dat beperkte motoriese vaardigheid meebring dat net korter reekse vooraf beplan kan word.

Die beplanning van 'n langer eenheid is waarskynlik om verskeie redes meer kompleks. Die byvoeging van addisionele klanke bring mee dat 'n groter getal kernmotorprogramme herroep moet word, die vereistes van ruimtelike en temporale adaptasie en koartikulasie neem toe en die groter getal bewegingspesifikasies moet in die korrekte volgorde vooruitgevoer word. Meer opeenvolgende variasie in bewegings kom ook voor in langer uitings. Dit is in die praktyk waargeneem dat $\mathrm{K}_{1} \mathrm{~V}_{1} \mathrm{~K}_{1} \mathrm{~V}_{1}$-eenhede by verbaal apraktiese sprekers soos by die normaal ontwikkelende kind vroeër voorkom en meer korrek geproduseer word. Die eenhede wat in hierdie studie gebruik is, is $\mathrm{K}_{1} \mathrm{~V}_{1} \mathrm{~K}_{1} \mathrm{~V}_{2}$ - en $\mathrm{K}_{1} \mathrm{~V}_{1} \mathrm{~K}_{2} \mathrm{~V}_{2}$-eenhede wat toenemend meer variasie in die bewegingspesifikasies meebring.

Indien die mate van variasie in die klanke wat voorkom, wel'n rol speel behoort die data dit te reflekteer. Hierdie moontlikheid word bevestig deur die resultate van die vokaalduurmetings (kyk tabel 4) waar die mate van afwyking by S2 groter is as by S1. By die uitingduurmetings (kyk tabel 5) word hierdie moontlikheid egter nie bevestig nie. S1 toon 'n groter mate van afwyking as S2. Dit wil dus voorkom asof die mate van variasie in die klanke in die eenheid nie die oorwegende rede is vir die verhoging in moeilikheidsgraad nie, maar eerder die getal klanke in die eenheid.

Laasgenoemde afleiding hou egter ook nie volkome stand nie. Dit wil voorkom asof die lengte van die uiting nie die enigste faktor is wat die moeilikheidsgraad daarvan bepaal nie want S5 bevat twee klanke meer as S3 maar vertoon feitlik dieselfde 
mate van afwyking in vokaalduur (kyk tabel 4) en 'n kleiner mate van afwyking in uitingduur (kyk tabel 5) as S3. Die feit dat $\mathrm{S} 5$ fonologies meer kompleks is omdat meer klanke geselekteer en gekombineer moet word as by S3, bring dus nie mee dat die afwyking in uitingduur toeneem nie. Die verbaal apraktiese spreker neem dus nie baie langer om dit te beplan as 'n uiting met vyf klanke soos in S3 nie.

Daar is verskillende moontlike verklarings vir die feit dat S3 feitlik dieselfde mate van afwyking vertoon vir vokaalduur en 'n groter mate van afwyking vir uitingduur as S5. Tydens die ondersoek is subjektief waargeneem dat S5 meer ritmies geproduseer word deur die verbaal apraktiese sprekers as $\mathrm{S3}$. Dit kan wees dat die ritme van 'n eenheid bepaal word deur die klankstruktuur en dat sekere strukture meer ritmies is. Keele en Summers (1976: 139) verklaar dat'n ritmiese tydstruktuur vaardighede anders beinvloed as 'n arbitrêre tydpatroon. Wanneer die tydreëling ritmies is, word die vaardigheid makliker aangeleer.

Dit word aanvaar dat die basiese eenheid van spraakritme die lettergreep is. Klankstruktuur drie bestaan uit twee lettergrepe, maar' $n$ neiging is waargeneem by die verbaal apraktiese sprekers om die KVKV-gedeelte as 'n eenheid te produseer en die finale /f/-klank as 'n geïsoleerde eenheid. Dit het moontlik meegebring dat die natuurlike spraakritme versteur is by S3. Die versteuring in spraakritme bring dan mee dat die uiting meer afwykend word.

'n Verdere moontlike verklaring wat by bogenoemde aansluit, is dat $\mathrm{S} 3$ problematies is omdat dit uit ' $\mathrm{n} \mathrm{KVKV}$-eenheid bestaan wat' $n$ duplisering is van die sogenaamde $K V$-eenheid van spraakprogrammering en 'n addisionele konsonant wat losstaande is. Die KVKV-struktuur kom ook soos reeds gemeld vroeg voor in kinderspraak en het waarskynlik beperkte kompleksiteit. Dit word dan as 'n eenheid geproduseer deur die sprekers. Dit mag ook wees dat lettergreepvorming versteur is, maar dit is onwaarskynlik want by $\mathrm{S} 5$ was daar geen probleme hiermee nie. By S5 vorm die KVKV-en die KVK-gedeeltes twee afsonderilke eenhede war peiat met redelike gemak geproduseer kan word terwyl die losstaande klank by S3 moontlik'n groter mate van beplanning verg.

Die probleme wat die proefpersone ervaar het met die produksie van S3-eenhede kan moontlik ook die gevolg wees van die spesifieke klank wat in die finale posisie voorkom. Die /f/ vereis akkurate aanpassing in lipbeweging en is minder veranderlik as baie ander klanke. Die /f/ kom aan die ander kant ook voor in S5 maar moontlik werk die daaropvolgende / $\mathbf{u}$ /- klank fasiliterend in op die /f / in hierdie eenhede. Die bewegings vir $\mathrm{die} / \mathrm{f} /$ in hierdie twee posisies en eenhede verskil.

Bogenoemde drie moontlike verklarings is die enigste wat voorgestel kan word op grond van die beskikbare data.

Opsommend kom die resultate daarop neer dat die klankstruktuur van 'n uiting 'n invloed uitoefen op die mate van afwyking in uitingduur. Die lengte van die uiting speel 'n belangrike rol. Kort uitings word feitlik normaal geproduseer wat die temporale eienskappe vokaalduur en uitingduur betref. Die byvoeging van 'n enkele klank bring mee dat produksie meer afwykend is. Die lengte van die uiting is egter nie die enigste faktor wat moeilikheidsgraad vir die verbaal apraktiese spreker bepaal nie. Die moontlikheid bestaan dat die besondere klankstruktuur van 'n uiting, die inherente ritme daarvan en/ of die klanke wat daarin voorkom, ook ' $n$ rol speel by die moeilikheidsgraad daarvan.
Die invloed van die artikulasie-eienskappe van 'n uiting op uitingduur.

Geeneen van die berekende P-waardes is onder 0,0125 nie, wat impliseer dat daar geen betekenisvolle verskille tussen die mate van afwyking in uitingduur van eenhede in die verskillende artikulasie-eienskapgroepe is nie.

Die P-waardes wat verkry is, is egter kleiner as die P-waardes vir vokaalduur. Die kleinste waarde vir vokaalduur is 0,4010 terwyl die grootste P-waarde vir uitingduur 0,4202 is. Die kleinste waarde is 0,0713 wat vir artikulasie-eienskapgroepe binne $\mathrm{S} 1$ verkry is. Numeries is daar ook groot verskille tussen die totaalwaardes vir die verskillende artikulasie-eienskapgroepe (kyk tabel 5). Dit wil voorkom asof daar tog verskille is tussen die mate waarin die uitingduur van eenhede in verskillende artikulasie-eienskapgroepe afwyk. 'n Moontlike verklaring vir die feit dat die invloed op vokaalduur meer beperk is, is waarskynlik dat verlengde vokaalduur slegs'n gedeelte van die invloed van artikulasie-eienskappe reflekteer. Die data oor uitingduur reflekteer die totale invloed en is daarom meer opsigtelik.

Dit moet in gedagte gehou word dat die artikulasie-eienskappe wat in die eenhede binne'n struktuurgroep verteenwoordig is, net minimaal verskil. Uiting 1.1 en 1.2 en ook 1.3 en 1.4 verskil byvoorbeeld net met ' $n$ enkele klank. Dit is dus insiggewend dat hierdie klein verskille in artikulasie-eienskappe wel die groot verskil in totaalwaardes teweegbring. Die totale afwyking in millisekondes vir A1 is 12554 terwyl dit vir A3 9907 is (kyk tabel 5). Die verskille tussen die artikulasie-eienskapgroepe word ook in groot mate gereflekteer in die totale vir die individuele sprekers. Dit wil dus voorkom asof die artikulasieeienskappe van 'n uiting wel 'n invloed uitoefen op die duur daarvan en moontlik dus op die moeilikheidsgraad van 'n uiting.

\section{GEVOLGTREKKINGS}

\section{Daar kan tot die volgende gevolgtrekkings gekom word:}

- Interartikulator-sinchronisasie vir korrekte stemgewing is nie sensitief vir die klankstruktuur of artikulasie-eienskappe van 'n uiting nie. Stemaanvangstydfoute kom onvoorspelbaar en onkonstant by die herhaling van 'n uiting voor. Die gebrek aan konteks-sensitiwiteit en die feit dat nie alle proefpersone stemaanvangstydfoute vertoon nie, dui daarop dat interartikulator-sinchronisasie vir korrekte stemgewing 'n komponent van beplanning is wat onafhanklik van die ander komponiente funksioneer en dat SAT-foute 'n kernsimptoom van verbale apraksie reflekteer. Die SAT-foute wat voorkom, is nie ware vervangings met stemlose klanke nie, maar is distorsies weens oorskryding van die kritiese temporale ekwivalensiegrense vir interartikulator-sinchronisasie.

- Variasie in die klankstruktuur van'n uiting het'n effek op vokaalduur. Vokaalduur is dus konteks-sensitief vir klankstruktuur. Namate die moeilikheidsgraad van die uiting toeneem, neem die mate van afwyking in vokaalduur ook toe. Die verlengde segmentele duur is dus nie'n direkte gevolg van die neuromotoriese afwyking by die verbaal apraktiese sprekers nie. Dit is waarskynlik 'n kompensatoriese strategie om die onderliggénde neuromotoriese probleem te oorkom. Sénsitiwiteit vir die temporale reël dat vokaalduur verkort voor' $n$ finale plosief, is behou. Die verbaal apraktiese sprekers is dus in staat om temporale aanpassings in die kernmotorprogram te maak 
Freeman, F.J., Sands, E.S. en Harris, K.S. Temporal coordination of phonation and articulation in a case of verbal apraxia: A voice onset time study. Brain and Language, 6, 106-111, 1978.

Hoit-Dalgaard, J., Murry, T. en Kopp, H.G. Voice-onset time production and perception in apraxic subjects. Brain and Language, 20 , $329-339,1983$.

Itoh, M. en Sasanuma,S. Articulatory movements in apraxia of speech. In J.C. Rosenbek, M.R. McNeil en A.E. Aronson (Reds.) Appraxia of Speech: Physiology, Acoustics, Linguistics, Management. San Diego: College-Hill Press, 1984.

Jansen, L.P.C. Persoonlike onderhoud, Forensiese Akoestiek-laboratorium van die Suid-Afrikaanse Polisie, Pretoria, 1985.

Jürgens, U. en Ploog, D. On the neural control of mammalian vocalization. Trends in Neurosciences, 4, 135-137, 1981.

Jürgens, U. en Von Cramon, D. On the role of the anterior cingulate cortex in phonation: A case report. Brain and Language, 15, 234$248,1982$.

Keele, S.W. en Summers, J.J. The structure of motor programs. In G.E. Stelmach (Red.) Motor Control: Issues and Trends. New York: Academic Press, 1976.

Kelso, J.A.S. en Tuller, B. Toward a theory of apractic syndromes. Brain and Language, 12, 224-245, 1981.

Kelso, J.A.S., Tuller, B. en Harris, K.S. A 'Dynamic Pattern' perspective on the control and coordination of movement. In P.F. MacNeilage (Red.) The Production of Speech. New York: SpringerVerlag, 1983.

Kent, R.D., Netsell, R. en Abbs, J.H. Acoustic characteristics of dysarthria associated with cerebellar disease. Journal of Speech and Hearing Research, 22, 627-648, 1979.

Die konsep van konteks-sensitiwiteit soos ontleen aan die koalisiemodel het dus ook met betrekking tot die temporale eienskappe van verbaal apraktiese spraak, die simptome in 'n insiggewende perspektief gestel deur die onderskeid tussen kernsimptome en geassosieerde simptome aan te toon. Verdere aanduidings van die aard van die afwyking is ook verkry. Die onvermoë om konstant die kritiese temporale ekwivalensiegrense vir interartikulator-sinchronisasie te bereik, is sigbaar gedemonstreer deur die akoestiese analise van herhaalde uitinge.

Die resultate van die ondersoek dui verder ook daarop dat dieselfde tweeledige simptomatologie, aangetref word by verbale ontwikkelingsapraksie.

\section{ERKENNINGS}

Finansiële bystand van diè Raad vir Geesteswetenskaplike Navorsing vir hierdie ondérsoek, word hiermee erken.

\section{VERWYSINGS}

Aitken, P.G. en Wilson, W.A. Discriminative vocal conditioning in rhesus monkeys: Evidence for volitional control? Brain and Language, 8, 227-240, 1979.

Blumstein, S.E., Cooper, W.E., Zurif, E.B. en Caramazza, A. The perception and production of voice-onset time in aphasia. Neuropsychologia, 15, 371-383, 1977.

Collins, M. Rosenbek, J.C. en Wertz, R.T. Spectrographic analysis of vowel and word duration. Journal of Speech and Hearing Research, 26, 224-230, 1983

Cooper, W.E. The development of speech timing, In S.J. Segalowitz en F.A. Gruber (Reds.) Language Development and Neurological Theory. New York: Academic Press, 1977.

Di Simoni, F.G. Influence of consonant environment on duration of vowels in the speech of three-, six and nine-year-old children. Journal of the Acoustical Society of America, 55, 362-363, 1974.

Duffy, J.R. en Gawle, C.A. Apraxic speaker's vowel duration in consonant-vowel-consonant syllables. In J.C. Rosenbek, M.R. McNeil en A.E. Aronson (Reds.) Apraxia of Speech: Physiology, Acoustics, Linquistics, Management. San Diego: College-Hill Press, 1984.
Kent, R.D. en Rosenbek, J.C. Acoustic patterns of apraxia of speech Journal of Speech and Hearing Research, 26, 231- 249, 1983.

Kewley-Port, D. en Preston, M.S. Early apical stop production: A voice onset time analysis. Journal of Phonetics, 2, 195-210, 1974.

Klapp, S.T., Anderson, W.G. en Berrian, R.W. Implicit speech in reading reconsidered. Journal of Experimental Psychology 100, 368$374,1973$.

Kubaska, C.A. en Keating, P.A. Word duration in early child speech. Journal of Speech and Hearing Research, 24, 615-621, 1981. sis of phonemic substitution erors in apraxia of speech. Journal of Communication Disorders, 12, 481-494, 1979.

Mogeson, G.J., Jones, D.L. en Yim, C.Y. From motivation to action: Functional interface between the limbic system and the motor system. Progress in Neurobiology, 14, 69-97, 1980.

Ploog, D. Neurobiology of primate audio-vocal behavior. Brain Research Reviews, 3, 35-61. Elsevier: North-Holland Bio-medical Press, 1981.

Rosenbek, J.C., Kent, R.D. en La Pointe, L.L. Apraxia of speech: An overview and some perspectives. In J.C. Rosenbek, M.R, McNeil en A.E. Aronson (Reds.) Apraxia of Speech: Physiology, Acoustics, Linguistics, Management. San Diego: College-Hill Press, 1984.

Schmidt, R.A. Motor Control and Learning: A Behavioral Emphasis. Illinois: Human Kinetics Publishers, 1982.

Turvey, M.T., Fitch, H.L. en Tuller, B. The Bernstein Perspective: I. The problems of degrees of freedom and context-conditioned variability. In J.A.S. Kelso (Red.) Human Motor Behavior: An Introduction. Iondon: Lawrence Erlbaum Associates, 1982.

Van der Merwe, A. Terapieprogram vir Verbale Ontwikkelingsapraksie sie van die Universiteit van Pretoria, Pretoria: V\&R, 1985.

Van der Merwe, A. Die motoriese beplanning van spraak by verbale apraksie. Ongepubliseerde D.Phil-verhandeling. Universiteit van Pretoria, 1986.

Van der Merwe, A., Uys, I.C., Loots, J.M. en Grimbeek, R.J. Die invloed van sekere kontekstuele faktore op die ouditief waarneembare foute by verbale apraksie. Die Suid-Afrikaanse Tydskrif vir Kommunikasieafwukings, 3, 10-22, 1987.

Van der Merwe, A., Uys, I.C., Loots, J.M. en Grimbeek, R.J. Ouditief waarneembare foute by verbale apraksie: Aanduidings van die aard van die afwyking. Die Suid-Afrikaanse Tydskrif vir Kommunikasieafwykings, 35, 45-54, 1988.

Wertz, R.T., La Pointe, L.L. en Rosenbek, J.C. Apraxia of Speech in Adults: The Disorder and its Management. Orlando: Grune \& Stratton, Inc., 1984.
Marquardt, T.P. Reinhart, J.B. en Peterson, H.A. Markedness analymet toepassingsmoontlikhede vir ander Spraakafwukings. Publika- 


\section{A LEGACY \\ OF SOUNDADVICE \\ AND EQUIPMENT}

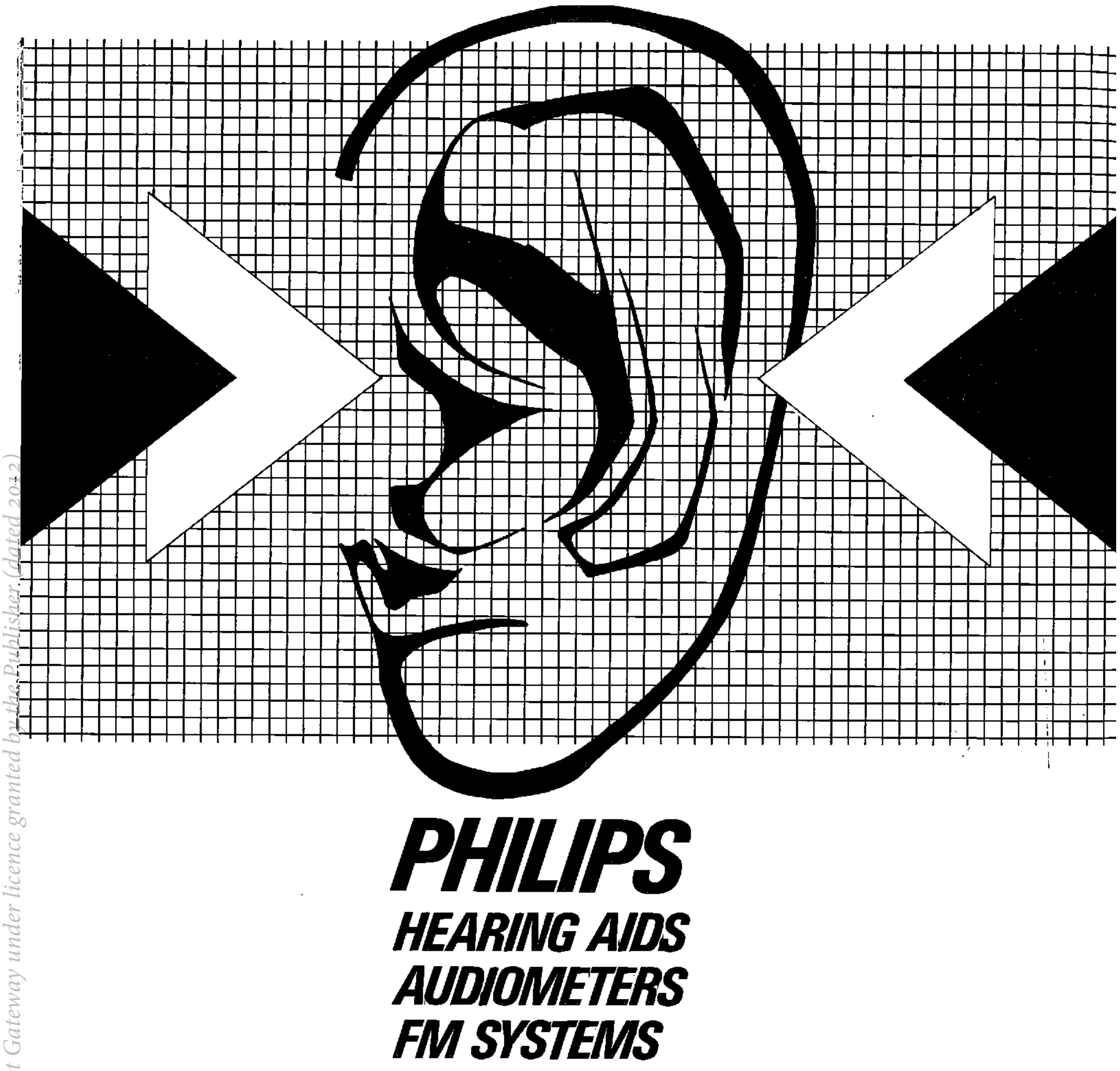

Head Office: 1005 Cavendish Chambers, 183 Jeppe Street

P.O. Box 3069, Johannesburg 2000. Tel: (011) 337.7537. 